\title{
Analiza konceptualnih mapa uz udžbenike u svrhu utvrđivanja mogućih konceptualnih poveznica za olakšano razumijevanje procesa razmnožavanja
}

\author{
Monika Golubić, Valerija Begić2, Ines Radanović \\ ${ }^{1}$ Osnovna škola Sunja, Ljudevita Posavskog 55 a, 44210 Sunja, Hrvatska \\ golubic.monika@gmail.com \\ ${ }^{2}$ Osnovna škola Sesvetski Kraljevec, Školska 10, 10361 Sesvetski Kraljevec, Hrvatska \\ ${ }^{3}$ Biološki odsjek, Prirodoslovno-matematički fakultet, Sveučilište u Zagrebu, Hrvatska
}

\begin{abstract}
SAŽETAK
Cilj ovog istraživanja je analiza konceptualnih mapa uz udžbenike Biologije za osnovnu školu u svrhu utvrđivanja mogućih konceptualnih poveznica za olakšano učenje. U ranijem istraživanju utvrđeno je postojanje problema kod usvojenosti koncepta razmnožavanje te su kao najizraženije uočene miskoncepcije uz ključni koncept životni ciklus stanice i organizma te kod razumijevanja koncepta oplodnje. Utvrđene miskoncepcije ukazuju na nužnu promjenu organizacije nastavnih sadržaja biologije, kao i na potrebu uvođenja novih nastavnih strategija $s$ naglaskom na aktivno sudjelovanje učenika. S obzirom na ograničenja nastavnog plana i programa prema kojem su mape pripremane kao sistematizacija uz nastavne teme, a ne kao podrška izgradnji ciljanog koncepta, uočeni problemi nisu u potpunosti podržani, iako omogućavaju 73 \% uspješno učenje uz djelomično razrješenje uočenih problema, pod uvjetom da se pravilno primjenjuju u nastavi. U pripremi konceptualne mape prema kurikulumu Biologije koji podržava konceptualni pristup učenju procijenjeno je da pripremljena ekspertna mapa podržava učenje uz razrješenje mogućih miskoncepcija u udjelu većem od $87 \%$.
\end{abstract}

Ključne riječi: konceptualno razumijevanje; analiza konceptualnih mapa; problemi u učenju i miskoncepcije u biologiji

\section{UVOD}

U posljednjih dvadesetak godina nastava biologije nastoji se unaprijediti radom na dubljem učeničkom razumijevanju znanstvenih principa i koncepata, umjesto na jednostavnoj reprodukciji znanstvenih činjenica (Momsen i sur, 2010; Wood, 2009). Dosadašnji oblici nastave i učenja od učenika su najčešće očekivali reprodukciju velikog broja činjenica, koje su učenicima nerijetko date u predavačkoj nastavi, bez stvaranja poveznica između različitih sadržaja u biologiji, kao niti između bioloških sadržaja i nastavnih sadržaja ostalih prirodnih znanosti (Radanović i sur, 2017a,b). Nastava biologije bi trebala uključivati nove znanstvene spoznaje vrlo brzo nakon njihova otkrića, a time se uzrokuje širenje opsega sadržaja koje učenici trebaju reproducirati. Upravo zbog brzog napretka znanosti i tehnologije u nastavi bi se trebao smanjiti naglasak na reprodukciju podatka, a povećati u područjima pronalaska, povezivanja i korištenja informacija. Zbog svega gore navedenog, sve više učitelja i nastavnika biologije svoju nastavu nastoji izvoditi konceptualnim pristupom.

Izraz "koncept", prema Hrvatskom jezičnom portalu, označava začeće ideje, pothvata, prvobitnu predodžbu ili zamisao o kakvom djelovanju, te u filozofskom smislu, nekakvu apstraktnu filozofsku spoznaju. S obzirom da čovjek tijekom cijelog života stječe nova iskustva, dolazimo do zaključka da se koncepti mogu nadopunjavati i mijenjati s obzirom na novostečene spoznaje (Bransford i sur, 2000). Kada se skup nekih spoznaja poveže te mu se dodijeli značenje na razini uopćavanja i apstrakcije, nastaje koncept (Bransford i sur, 2000; Lukša, 2011). Stvaranje koncepta je način pohranjivanja i organizacije informacija u dugoročnom pamćenju jer se na osnovi pojedinačnih primjera uočavaju pravilnosti i zajedničke karakteristike, obrasci koji se pamte (Vizek-Vidović i sur, 2003). Kod učenika se

Golubić, M., Begić, V., Radanović, I. 2019. Analiza konceptualnih mapa uz udžbenike u svrhu utvrđivanja mogućih konceptualnih poveznica za olakšano razumijevanje procesa razmnožavanja. Educ. biol., 5:48-67. URL DOI: https://doi.org/10.32633/eb.5.4 
biološki koncept može definirati kao mentalni model i prikaz doživljaja svijeta i razumijevanja bioloških pojava i procesa, koji se formira kao koncepcija, a podložan je utjecajima kao što su udžbenici i nastavnici (Glynn i Duit, 1995). Kad se govori o konceptima, jasno je da kod njihova stvaranja može doći do pogrešaka čiji je rezultat pogrešna predodžba, zabluda i nerazumijevanje činjenica što se naziva miskoncepcijama, odnosno pogrešno poimanje i način razmatranja pojave ili procesa od strane učenika. Mestre (2001) u definiciju miskoncepcija uključuje sva pogrešna shvaćanja bez obzira jesu li nastala tijekom nastavnog procesa ili van njega. Za miskoncepcije je karakteristično da se često pojavljuju kod većeg broja ljudi, otporne su na promjene, a često obuhvaćaju misaone konstrukcije s jakim vezama koje se teško mogu dekonstruirati jer imaju smisla osobama koje su ih stvorile (Fisher, 1985).

Prema Garašić i sur. (2013), u hrvatskom školstvu se programska koncepcija sadržaja biologije uglavnom nije mijenjala još od 1960. godine, a svi pokušaji promjene i reforme nastave biologije bili su neuspješni, jer se nisu temeljili na rezultatima znanstvenih istraživanja u području edukacije biologije. Tek se 2010. godine, uvođenjem Nacionalnog okvirnog kurikuluma, događa napredak jer se biologija ne promatra samostalno, već se smješta u prirodoslovno područje i korelira s ostalim predmetima u tom području (Garašić i sur, 2013). U sklopu istraživanja Kompetencije učenika u nastavi prirode i biologije izrađen je prvi prijedlog osnovnih makrokoncepata u nastavi biologije (Lukša i sur, 2013a), koji uključuje šest makrokoncepata: Ustrojstvo živih bića, Energija, Ravnoteža, Raznolikost, Međuovisnost i Razmnožavanje. Ovakav prijedlog biološkog konceptualnog okvira imao je ulogu organizirati biološke sadržaje u makrokoncepte te usmjeriti učitelje i nastavnike, pri sastavljanju ispitnih pitanja, prema promišljanju u okviru viših kognitivnih razina i ključnih koncepata u biologiji. Istim je istraživanjem utvrđeno da kod učenika prevladava reproduktivno znanje jer je njihova uspješnost padala prema višim kognitivnim razinama.

Kako bi se osuvremenio pristup pripremanja nastave te preciznije odredio sadržaj i način provjere znanja na državnoj maturi, pripremljen je Katalog državne mature za biologiju (Radanović i sur, 2015) koji je nastao revidiranjem prethodno spomenutih konceptualnih okvira u biologiji (Lukša, 2011; Garašić, 2012; Lukša i sur, 2013). Novonastali katalog uključuje elemente sadržajnog i konceptualnog pristupa u nastavi biologije, a izrađen je kako bi se nastavni sadržaj biologije smisleno organizirao te kako bi se tvorile unutarnje poveznice između različitih sadržaja. lako se nastava biologije u hrvatskim školama izvodi prema važećem nastavnom planu i programu, organizacija Kataloga prema makrokonceptima daje smjernice za izgradnju temeljnih bioloških koncepata tijekom učenja i poučavanja. Katalogom državne mature za biologiju, definirano je pet područja koja odgovaraju makrokonceptima u biologiji: Organiziranost živoga svijeta, Razmnožavanje i razvoj organizama, Tvari i energija u životnim procesima, Ravnoteža i međuovisnosti u živome svijetu te Biološka pismenost. Ovakav konceptualni okvir predviđen je za primjenu tijekom poučavanja biologije u osnovnim i srednjim školama, a ne samo u gimnazijskom programu kao završnoj razini općeobrazovnog učenja biologije, te se kao takav može sustavno primjenjivati za kreiranje nastave u svrhu konceptualnog poučavanja biologije. S obzirom da je njegova primjena omogućila smisleno organiziranje bioloških sadržaja poslužio je i kao polazišna točka pri izradi konceptualnog okvira Kurikuluma nastavnog predmeta Biologija za osnovne škole i gimnazije (MZO, 2019). Kurikulumom Biologije ranije korišteni konceptualni okvir modificiran je u skladu s konceptualnim okvirom Prirodoslovnog područja kurikuluma (MZO, 2017) te su definirana četiri makrokoncepta: A. Organiziranost živoga svijeta, B. 
Procesi i međuodnosi u živome svijetu, C. Energija u živome svijetu, D. Prirodoznanstveni pristup. Razmnožavanje je pri tome uvršteno u makrokoncept Procesi i međuovisnosti u živome svijetu.

Korištenje taksonomske tablice u nastavi, prema Krathwohlu (2002), omogućuje učiteljima i nastavnicima da unaprijede planiranje nastave i način rada u svrhu ostvarivanja željene razine usvojenosti nastavnog sadržaja kod učenika. Prema Garašić i sur. (2013), učitelji i nastavnici Prirode i Biologije u Republici Hrvatskoj odabrali su u nastavi primjenjivati prilagođeni Crooksov model kognitivnog područja (Crooks, 1988). Taj model se primjenjuje u nastavi Prirode i Biologije unatrag desetak godina tijekom kurikulumskog kruga pripreme poučavanja i učenja, kao i za potrebe planiranja vrednovanja te pri analizi rezultata ostvarenih na nacionalnoj razini (Radanović i sur, 2010; 2017a,b). Reproduktivno znanje je temeljeno na memoriranju činjenica, obuhvaća reprodukciju zaključaka i objašnjenja usvojenih tijekom učenja ili iz literaturnih izvora te razumijevanje teksta. Razumijevanje i primjena uključuju konceptualno razumijevanje sadržaja koje je rezultat konceptualne promjene tijekom učenja i osnova je trajnog znanja. Do konceptualnog razumijevanja često se dolazi u potrebi primjene znanja kada se moraju stvoriti veze iz prethodno postojećih znanja i onih novostečenih. Razina rješavanja problema prema Bloomovoj taksonomiji obuhvaća analizu, vrednovanje i stvaranje.

S obzirom da se još uvijek nedovoljno provjerava konceptualno razumijevanje učenika, prethodno opisani biološki konceptualni okviri trebali bi se koristiti kao instrument upravo za oblikovanje zadataka kojima će se provjeravati konceptualno razumijevanje. U tu svrhu učitelji i nastavnici često u nastavu uvode istraživački pristup, koji se međutim nije pokazao uspješnim za uklanjanje pogrešnih koncepcija (Barker i Carr, 1989). Isti autori predlažu konstruktivistički pristup nastavi u kojem se utvrđuju predkoncepcije učenika, a na primjeru fotosinteze utvrdili su je da čak 71 \% učenika po završetku nastave postiže konceptualno razumijevanje. Osim toga, nastavne strategije koje zahtijevaju aktivni angažman učenika smatraju se korisnijima i efikasnijima u otklanjanju miskoncepcija i dostizanju konceptualne promjene. Jedan od najučinkovitijih pristupa jest učenje otkrivanjem, koje povećava mogućnosti suočavanja s miskoncepcijama (Lorenzo i sur, 2006; Lukša, 2011), a kao rezultat ima bolje vještine u znanstvenom rasuđivanju i konceptualno razumijevanje. Bez obzira na to što se stručnjaci slažu da je ova strategija poučavanja izrazito korisna i efikasna, njena primjena u nastavi u svim razinama obrazovanja još uvijek nije raširena.

Osim tipičnog oblika korištenja pitanja s višestrukim odgovorima, u svrhu provjeravanja konceptualnog razumijevanja mogu se koristiti alternativne metode vrednovanja, poput kreiranja konceptualnih mapa (Novak i Cañas, 2008). Konceptualne mape grafički su alat za organiziranje i reprezentaciju znanja, a uključuju koncepte i konceptualne poveznice (Novak i Cañas, 2008). Upotreba konceptualnih mapa u nastavi ima za cilj postići što višu razinu kognitivnih sposobnosti učenika (Latin i sur., 2016). Korištenje konceptualnih mapa u nastavi omogućuje jasniji uvid u razlike među učeničkim strukturama znanja (Ruiz-Primo i sur, 2001) te se mogu primijeniti kao alat za procjenu znanja i konceptualnog razumijevanja kod učenika (Novak i Cañas, 2008). Korištenje konceptualnih mapa pri učenju kod učenika hrvatskih srednjih škola pokazalo se uspješnom metodom učenja, jer su učenici koji su učili uz konceptualne mape u usporedbi s tradicionalnim metodama učenja i poučavanja pokazali bolje rezultate pri provjeravanju znanja viših kognitivnih razina, a pokazana je i bolja retencija znanja (Latin i sur, 2016). 
Cilj ovog istraživanja je analiza konceptualnih mapa uz udžbenike Biologije za osnovnu školu u svrhu utvrđivanja mogućih konceptualnih poveznica za olakšano učenje. U svrhu ostvarenja cilja, istraživanjem se žele predložiti konceptualne poveznice koje mogu utjecati na smanjivanje miskoncepcija i podržati kvalitetnu izgradnju koncepta razmnožavanja kod učenika pri poučavanju u osnovnoj školi. Utvrđene miskoncepcije i konceptualne poveznice ukazat će učiteljima biologije na promjene koje su neophodne u planiranju nastave u osnovnoj školi kako bi se uspješno otklonile miskoncepcije i omogućila kvalitetna izgradnja koncepta Razmnožavanje.

\section{METODE}

Analizirane su ekspertne konceptualne mape uz udžbenike biologije za 7. i 8. razred (Begić i sur, 2014; Bastić i sur, 2014) te mapa uz udžbenik Biologija 8 koji je izrađen prema kurikulumu Biologije (Begić i sur, 2019), a u svrhu utvrđivanja konceptualnih poveznica i načina izgradnje koncepata kao osnova za neophodno i napredno konceptualno razumijevanje razmnožavanja za učenike u osnovnoj školi. Konceptualne poveznice ekspertnih konceptualnih mapa uz udžbenike analizirane su prema Radanović i sur. (2017c), a na temelju uputa koje predlažu Novak i Cañas (2008). Kako bi se mogao procijeniti potencijalni značaj pripreme pojedine konceptualne osnove u ekspertnoj mapi za razrješenja problema i miskoncepcija uz koncepte za koje su analizom uspjeha učenika na natjecanju utvrđeni problemi razumijevanja, u svakoj ekspertnoj mapi su kvantitativno izraženi elementi procjene: korišteni pojmovi, poveznice između pojmova, riječi povezivanja i omogućeno konceptualno razumijevanje. Na osnovi analize korištenih pojmova identificirani su i kvantificirani ključni koncepti prikazani u mapi s obzirom da su mape zbog aktualnog plana i programa, odnosno kurikuluma, izrađene kao podrška sistematizaciji nastavnih tema. Konceptualno razumijevanje je procijenjeno i kvalitativno, prilagođeno prema kriterijima predloženim prema Kinchin i Hay (2000) uz kategorije procjene povezanosti, složenosti i omogućenog konceptualnog razvoja u kombinaciji s modelom za utvrđivanje konceptualne kvalitete pitanja u udžbenicima prema Yaman (2017). Ključni procesi koje učenici koriste pri učenju uz konceptualne mape omogućavaju utvrđivanje razine konceptualne kvalitete pitanja (Costa, 1985; Yaman, 2017) i odnose se na misaone procese usmjerene na ulaz, obradu ili izlaz koje izazivaju predočene informacije i usmjereni su na analizu mogućnosti postavljanja pitanja pri učenju i provjeravanju (tablica 1). Interpretacijom modela može se uočiti povezanost s kognitivnim razinama učenja koje bi organizacija konceptualne mape i predočene poveznice trebale omogućiti učenicima (tablica 1).

Tablica 1 Kriteriji za kvalitativnu procjenu konceptualnog razumijevanja koje omogućavaju konceptualne mape (prilagođeno prema Kinchin i Hay (2000) i Costa (1985) Costa (1985)

\begin{tabular}{|c|c|c|c|c|c|c|}
\hline \multicolumn{2}{|r|}{ Ključni procesi } & Primjeri pitanja & Povezanost & Složenost & $\begin{array}{l}\text { Konceptualni } \\
\text { razvoj }\end{array}$ & $\begin{array}{l}\text { kogitivna } \\
\text { razina }\end{array}$ \\
\hline 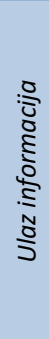 & $\begin{array}{c}\text { identifikacija, } \\
\text { dovršavanje, unos, } \\
\text { odabir, } \\
\text { promatranje, } \\
\text { pripovijedanje, } \\
\text { sažimanje, } \\
\text { sjećanje... }\end{array}$ & $\begin{array}{c}\text { - Koji je najbolji korišten } \\
\text { izraz koji opisuje ovaj dio } \\
\text { prikaza? } \\
\text { - Koji su pojmovi navedeni, } \\
\text { a neophodni su za } \\
\text { razumijevanje prikazanog } \\
\text { procesa? } \\
\text { - Postoji li sažetak } \\
\text { događaja/procesa u ovom } \\
\text { prikazu? }\end{array}$ & $\begin{array}{c}\text { jednostavna } \\
\text { povezanost }\end{array}$ & $\begin{array}{c}\text { mala } \\
\text { mogućnost } \\
\text { integracije } \\
\text { dodatnih } \\
\text { koncepata }\end{array}$ & $\begin{array}{c}\text { malo ili nimalo } \\
\text { integrirano, ali } \\
\text { može podržati } \\
\text { razvoj osnovnog } \\
\text { prikaza } \\
\text { razumijevanja }\end{array}$ & Reprodukcija \\
\hline
\end{tabular}




\begin{tabular}{|c|c|c|c|c|c|c|}
\hline \multicolumn{3}{|c|}{ Costa (1985) } & \multicolumn{3}{|c|}{ Kinchin i Hay (2000) } & \multirow{2}{*}{$\begin{array}{c}\text { Omogućena } \\
\text { kogitivna } \\
\text { razina }\end{array}$} \\
\hline & Ključni procesi & Primjeri pitanja & Povezanost & Složenost & $\begin{array}{l}\text { Konceptualni } \\
\text { razvoj }\end{array}$ & \\
\hline $\begin{array}{l}0 \\
0 \\
0 \\
0 \\
5 \\
0 \\
5 \\
5 \\
0 \\
0 \\
0 \\
0 \\
0\end{array}$ & $\begin{array}{c}\text { uspostavljanje uzročno- } \\
\text { posljedičnog odnosa, } \\
\text { analiza, } \\
\text { sinteza, usporedba, } \\
\text { zaključivanje, } \\
\text { uređivanje, } \\
\text { odabir, razvrstavanje, } \\
\text { klasifikacija, stvaranje } \\
\text { analogije ... }\end{array}$ & $\begin{array}{c}\text { - Koji je razlog ovog prikaza } \\
\text { događaja/procesa? } \\
\text { - Kakav je odnos između } \\
\text { pojedinih prikazanih } \\
\text { događaja/procesa? } \\
\text { - Što razlikuje prikazane } \\
\text { dijelove mape jedne od } \\
\text { drugih? }\end{array}$ & $\begin{array}{l}\text { prikazana } \\
\text { osnovna } \\
\text { slijednost }\end{array}$ & $\begin{array}{c}\text { koncepti se } \\
\text { mogu } \\
\text { oplemeniti s } \\
\text { manjim } \\
\text { dodacima }\end{array}$ & $\begin{array}{l}\text { reorganizacija ili } \\
\text { gubitak veze } \\
\text { ukazuje na } \\
\text { izolirano } \\
\text { isticanje malog } \\
\text { utjecaja bez } \\
\text { preglednog } \\
\text { shvaćanja }\end{array}$ & $\begin{array}{c}\text { Primjena i } \\
\text { konceptualno } \\
\text { razumijevanje }\end{array}$ \\
\hline $\begin{array}{l}0 \\
0 \\
0 \\
E \\
5 \\
0 \\
: \\
\frac{1}{N} \\
\frac{N}{N}\end{array}$ & $\begin{array}{c}\text { prakticiranje načela, } \\
\text { mašta, planiranje, } \\
\text { vrednovanje, } \\
\text { oblikovanje hipoteza, } \\
\text { generalizacija, } \\
\text { uspostavljanje modela }\end{array}$ & $\begin{array}{l}\text { - Je li prikazano najbolje } \\
\text { rješenje za uklanjanje } \\
\text { mogućih problema u učenju } \\
\text { i poučavanju i } \\
\text { miskoncepcija? } \\
\text { - Što se mijenja ako } \\
\text { zamijenimo određeni pojam } \\
\text { mape s nekim sličnim ili } \\
\text { srodnim pojmom? } \\
\text { - Kako } \\
\text { razmišljanje/djelovanje na } \\
\text { prikazani način utječe na } \\
\text { konceptualno } \\
\text { razumijevanje? }\end{array}$ & $\begin{array}{c}\text { sekvence } \\
\text { razumijevanja } \\
\text { u } \\
\text { interakcijama }\end{array}$ & $\begin{array}{l}\text { slijedni putovi } \\
\text { su dostupni i } \\
\text { osigurani pri } \\
\text { dodavanju } \\
\text { više } \\
\text { integracijskih } \\
\text { sekvenca - } \\
\text { uklopivo u } \\
\text { drugu mapu }\end{array}$ & $\begin{array}{c}\text { veći dio } \\
\text { poveznica može } \\
\text { se izgubiti bez } \\
\text { promjene } \\
\text { značenja cjeline } \\
\text { za } \\
\text { razumijevanje, } \\
\text { jer } \\
\text { pretpostavlja i } \\
\text { lanac koji } \\
\text { nedostaje }\end{array}$ & $\begin{array}{c}\text { Rješavanje } \\
\text { problema }\end{array}$ \\
\hline
\end{tabular}

Pitanja izdvojena iz provjera Županijskog natjecanja iz biologije uz makrokoncept Razmnožavanje $i$ razvoj organizma detaljno su analizirana (Golubić i sur, 2017) te će se na osnovu tih rezultata utvrditi mogućnosti organizacije učenja za razrješenje uočenih problema i miskoncepcija za konceptualno povezivanje uz primjenu konceptualnih mapa.

\section{REZULTATI}

Rezultati donose analizu pet konceptualnih mapa koje uključuju koncepte važne za razumijevanje nadređenog koncepta Razmnožavanje i razvoj organizma za učenike u osnovnoj školi, a ponuđene su učenicima u radnim bilježnicama za sistematizaciju znanja (prilozi od 1 do 5). Također je analizirana $i$ konceptualna mapa izrađena uz koncept Razmnožavanje u skladu s konceptualnim pristupom učenja Kurikuluma Biologije (prilozi 6 i 7).

\section{Analiza ekspertnih konceptualnih mapa}

U nastavi biologije u osnovnim školama u Republici Hrvatskoj, koriste se udžbenici uz koje su predložene konceptualne mape koje popunjavaju učenici, a služe za konstrukciju znanja, te kao priprema za pisanu provjeru znanja. U izradi ovog rada analizirane su konceptualne mape uz udžbenike biologije za 7. i 8. razred koje uključuju koncepte unutar makrokoncepta Razmnožavanje i razvoj organizma, a prilozi su udžbenicima Biologija 7 (Begić i sur, 2014) i Biologija 8 (Bastići sur, 2014). Konceptualne mape uz udžbenik trebali bi koristiti učitelji pri poučavanju te učenici kao pomagalo za učenje i razvoj konceptualnog razumijevanja. Mape su osmišljene tako da se u predlošku nalaze neki od ključnih koncepata (ključnih pojmova za koncept) te su upisane poveznice između svih koncepata (pojmova), a učenici prema poveznicama i tumačenjem značenja boja korištenih u mapi trebaju upisati preostale, ponuđene ključne pojmove u prazne okvire.

Konceptualna mapa uz temu Od najjednostavnijeg oblika života do stanice povezuje makrokoncepte Organiziranost živoga svijeta, Procesi i međuodnosi u živome svijetu, Energija u živome svijetu, Prirodoznanstveni pristup. Makrokoncept Razmnožavanje i razvoj organizama zastupljen je ključnim konceptima životni ciklus stanice i molekularna osnova nasljeđivanja te oblici razmnožavanja. 
Hijerarhijski najviši, temeljni koncept jest stanica, što je vizualno lako uočiti zbog dobre grafičke organizacije mape. Izdvojeni koncepti i ključni pojmovi na različitim su razinama hijerarhije, što je u mapi naglašeno po oblikovanju i sjenčanju tekstualnih okvira. Poveznice između koncepata sažete su, jasne i odražavaju važne veze između koncepata. Poveznice su napisane tako da učenici koji imaju znanje na razini razumijevanja i primjene mogu lako zaključiti koji koncept/ključni pojam je potrebno upisati na prazno mjesto u mapi, tako da se od dva povezana koncepta/ključna pojma i njihove poveznice može tvoriti smislena, točna izjava. Kod nekih dijelova mape za rješavanje dostatno je znanje nastavnog sadržaja na reproduktivnoj razini. Između različitih segmenata u mapi koji odgovaraju makrokonceptima u biologiji postoje poveznice, međutim u organizaciji mape teže ih je uočiti nego poveznice unutar jednog makrokoncepta. Ključni koncepti životni ciklus stanice i oblici razmnožavanja povezani su s konceptom ustrojstvo živih bića i raznolikost, svaki s po jednom poveznicom. Upisivanjem odgovarajućih pojmova u predviđene okvire u predlošku mape, učenici mogu iskoristiti znanje koje imaju na reproduktivnoj razini te pomoću mape kao pomagala za učenje, organizirati usvojeno znanje te izgraditi konceptualno razumijevanje. Izgradnja konceptualnog razumijevanja olakšana je time što su koncepti u mapi i njihove međusobne poveznice organizirani tako da učenici, prateći usmjerenost poveznica između koncepata, mogu postupno pročitati skup izjava koje tvore smislenu tematsku cjelinu te se međusobno nadopunjuju u objašnjavanju početnog koncepta. Kod rješavanja mape, kod učenika se mogu provjeriti neka od obrazovnih postignuća iz Nacionalnog plana i programa za osnovne škole (MZOŠ, 2006), posebno ona koja su važna za izgradnju ključnih bioloških koncepata kao što je usporedba broja kromosoma u stanicama koje nastaju mitozom i mejozom, uloga procesa oplodnje i razvoj višestaničnog organizma. Provjerava se znaju li učenici razlikovati mitozu i mejozu, a također se provjeravaju ishodi vezani uz nastavne teme predmeta Priroda u 5. razredu, kada se od učenika očekuje da razlikuju različite uloge diobe stanica kod jednostaničnih i višestaničnih organizama.

Konceptualna mapa Razvoj kralježnjaka povezuje makrokoncepte Organiziranost živoga svijeta, Razmnožavanje i razvoj organizama, Tvari i energija u životnim procesima, koji su u mapi vizualno odijeljeni rasporedom pojmova te upotrebom različitih boja. Iz makrokoncepta Razmnožavanje i razvoj organizama izdvaja se ključni koncept oblici razmnožavanja. Hijerarhijski temeljni koncept (pojam) jest kralježnjaci, što je lako uočljivo po smještaju pojma u centar mape. S temeljnim konceptom razmnožavanje je povezano preko koncepta spolno razmnožavanje, a zatim se grana na pojmove unutarnja i vanjska oplodnja. Ne postoje druge poveznice koncepta razmnožavanja s ostalim konceptima prikazanima u mapi. Makrokoncept Razmnožavanje i razvoj organizama najmanje je zastupljen koncept u ovoj konceptualnoj mapi. Poveznice između koncepata jasne su, sažete i dobro prikazuju odnose između izabranih pojmova. Upotreba boja u mapi olakšava učenicima praćenje sadržaja u mapi i organizaciju znanja te razvijanje konceptualnog razumijevanja, što bi u suprotnom vjerojatno izostalo zbog opsežnosti mape i količine poveznica. Koncepti vezani uz razmnožavanje u mapi nisu razrađeni na način da bi za njihovo rješavanje bilo potrebno znanje na razini primjene i konceptualnog razumijevanja, nego je dostatno reproduktivno znanje, što je utjecano naglascima Nastavnog programa biologije u 7. razredu osnovne škole. Kod ispunjavanja mape ne možemo provjeriti učeničko razumijevanje međusobnih odnosa prednosti i nedostataka unutarnje i vanjske oplodnje niti njihovu povezanost s životnim uvjetima u kojima odgovarajuće skupine životinja žive, što su važnija obrazovna postignuća u 7. razredu.

Mapa Razvoj biljaka uključuje makrokoncepte Organiziranost živoga svijeta, Razmnožavanje i razvoj organizama, Tvari i energija u životnim procesima, Ravnoteža i međuovisnosti u živome svijetu. Pojedini 
koncepti su međusobno vizualno odijeljeni rasporedom pojmova u mapi i upotrebom različitih boja. Makrokoncept Razmnožavanje i razvoj organizama zastupljen je kroz ključne koncepte oblici razmnožavanja i opstanak vrsta. U mapi se kao temeljni koncept izdvaja pojam kopnene biljke, koji se grananjem povezuje s uključenim makrokonceptima. Makrokoncept Razmnožavanje i razvoj organizama povezan je s temeljnim konceptom preko pojmova mahovine, papratnjače i sjemenjače, a postoje i poveznice s konceptima uz životne uvjete. Koncept razmnožavanja dobro je zastupljen u ovoj konceptualnoj mapi. Poveznice između elemenata u mapi jasne su i sažete te pridonose razumijevanju međuodnosa izabranih koncepata. Poveznice se mogu lako pratiti te njihovim čitanjem učenik može, uz nadopunjavanje praznina u okvirima za koncepte, stvoriti smislenu tematsku cjelinu izjava koje se međusobno nadopunjuju u obrazlaganju koncepta koji ih međusobno povezuju kao koncept više razine u hijerarhiji pojmova. Za rješavanje dijelova konceptualne mape vezanih uz razmnožavanje, kod učenika je u većem dijelu dovoljno konceptualno znanje koje se rješavanjem mape može organizirati te omogućiti izgradnju znanja na razini primjene i konceptualnog razumijevanja. Rješavanjem konceptualne mape kod učenika se može provjeriti ispunjenje nekoliko obrazovnih postignuća za biologiju u 7. razredu, kao što je opisivanje načina razmnožavanja mahovina i paprati, ali i ishode koji se spominju u Ispitnom katalogu državne mature (NCVVO, 2016), gdje učenici trebaju povezati načine razmnožavanja sa životnim uvjetima određenih skupina biljaka.

Konceptualna mapa Srodnost, raznolikost i nasljeđivanje gotovo isključivo prikazuje makrokoncept Razmnožavanje i razvoj organizama uz mali broj poveznica i koncepata vezanih uz Organiziranost živoga svijeta. Ključni koncepti unutar makrokoncepta Razmnožavanje i razvoj organizama u mapi su odijeljeni rasporedom pojmova i upotrebom različitih boja. Kao temeljni koncept izdvaja se DNA, koji se povezuje s ključnim konceptima molekularne osnove nasljeđivanja te oblika razmnožavanja. U mapu je uključen i ključni koncept ljudske reprodukcije, s obzirom da se nastavni sadržaji biologije u osmom razredu bave proučavanjem čovjeka. Poveznice između pojmova i koncepata jasne su, sažete i dobro opisuju međusobne veze između pojmova. Njihovim se čitanjem, kao i kod prethodnih mapa, može složiti tematski smislena cjelina izjava koje se međusobno nadopunjuju. Za manji dio mape dovoljno je znanje učenika na reproduktivnoj razini, ali uglavnom je potrebna razina razumijevanja. Učenici koji nemaju dostatno znanje na razini razumijevanja mapu bi mogli uspješno riješiti pomoću udžbenika. Rješavanjem mape kod učenika se može provjeriti velik broj obrazovnih postignuća predviđenih za osmi razred: opisati gene kao nositelje nasljednih osobina, razlikovati spolno od nespolnog razmnožavanja, istaknuti da pri spolnom razmnožavanju sudjeluju oba roditelja - žena/ženka $\mathrm{i}$ muškarac/mužjak, odnosno ženska jajna stanica i muška spolna stanica - spermij te da su potomci raznoliki, obrazložiti važnost genske raznolikosti za opstanak života, opisati kako muške spolne stanice (spolni kromosomi X i Y) određuju spol, navesti što je genom, obrazložiti da se genom sastoji od DNA molekula, imenovati DNA i RNA kao nasljednu tvar, istaknuti da DNA sadržava gene koji su nositelji nasljednih svojstava, objasniti što su mutacije (promjene), istaknuti važnost mutacija koje se prenose na potomstvo i glavni su pokretač prilagodbe živih organizama, obrazložiti da mutacije mogu nositi upute za razvoj bolesti koje su tada nasljedne (MZOŠ, 2006).

Konceptualna mapa Sastav tijela, razmnožavanje i razvitak vezana je gotovo isključivo uz izgradnju makrokoncepta Razmnožavanje i razvoj organizama i Organiziranost živoga svijeta te posebno ključnog koncepta ljudska reprodukcija uz mali broj poveznica i koncepata vezanih uz makrokoncept Ravnoteža i međuovisnosti u živome svijetu. Mapa je organizacijom pojmova i upotrebom boja podijeljena na nekoliko segmenata. Ne izdvaja se temeljni koncept koji je hijerarhijski na višoj razini od 
ostalih. Poveznice u mapi su jasne, sažete i smisleno povezuju koncepte. Usmjerenost poveznica olakšava čitanje mape. Za rješavanje mape u velikom omjeru je dostatno znanje na reproduktivnoj razini koje se tijekom učenja pomoću konceptualne mape može razviti u znanje na razini primjene $i$ konceptualnog razumijevanja. Predložak konceptualne mape može se iskoristiti za provjeravanje očekivanih obrazovnih postignuća za osmi razred, kao što su: povezati građu i ulogu spolnih organa; istaknuti važnost poznavanja menstruacijskog ciklusa; opisati pojavu menstruacije kao znak spolne zrelosti organizma i mogućnosti oplodnje, povezati menstruacijski ciklus s plodnim i neplodnim danima, navesti osnovne načine kontracepcije i obrazložiti ulogu kontracepcije, opisati razvoj ploda prije rođenja, razlikovati pojmove trudnoća i porođaj, opisati ulogu posteljice i pupčane vrpce, razlikovati pojmove zametak i plod (MZOŠ, 2006). Pojmovi uz koncept razmnožavanje slabo su u mapi povezani s ostalim makrokonceptima. Postoji jedna poveznica i to između koncepata organi i spolni organi, dok ostali dijelovi mape nisu povezani. Jedan od razloga takvog opredjeljenja pri izradi ove konceptualne mape je i njeno ograničenje zadanim formatom kao i velik broj pojmova neophodnih za izgradnju ovih koncepata bitnih ne samo za biologiju, već i za život.

Procjena podrške postojećih objavljenih 5 ekspertnih mapa za otklanjanje utvrđenih problema i miskoncepcija (tablica 2) ukazuje da niti jedan od uočenih problema nije u potpunosti podržan kako bi omogućio razrješenje miskoncepcije kod svih učenika. Najmanju podršku konceptualnom razvoju pružaju mape Razvoj kralježnjaka i Razvoj biljaka, što je razumljivo s obzirom da se temelje na nastavnom programu koji je posebno u ovim dijelovima izrazito deskriptivan te se bazira na morfološkim karakteristikama organizama bez poveznica na razloge njihove organizacije u skladu sa životnim uvjetima.

Tablica 2 Analiza mogućnosti potpore u učenju i razrješavanju uočenih problema u razumijevanju u postojećim ekspertnim mapama uz udžbenike Biologija 7 (Begić i sur, 2014) i Biologija 8 (Bastić i sur, 2014)

\begin{tabular}{|c|c|c|c|c|}
\hline $\begin{array}{l}\text { Uočeni problemi } \\
\text { u razumijevanju }\end{array}$ & Mapa & POVEZANOST & $\begin{array}{c}\text { OMOGUĆENO } \\
\text { KONCEPTUALNI RAZVOJ }\end{array}$ & $\begin{array}{l}\text { RAZRJEŠENJE PROBLEMA ILI } \\
\text { MISKONCEPCIJE }\end{array}$ \\
\hline \multirow{6}{*}{$\begin{array}{l}\text { Broj kromosoma } \\
\text { u } \\
\text { tjelesnim/spolnim } \\
\text { stanicama }\end{array}$} & & $\checkmark$ & \pm & \pm \\
\hline & $\begin{array}{c}\text { Od } \\
\text { najjednostavnijeg } \\
\text { oblika života do } \\
\text { stanice }\end{array}$ & $\begin{array}{l}\text { U mapi je uporabom oznaka }(2 n \text { i } n) \\
\text { naglašen broj kromosoma u tjelesnim i } \\
\text { spolnim stanicama, kao i u oplođenoj } \\
\text { jajnoj stanici, za koju je prikazano da se } \\
\text { dalje dijeli mitozom u svrhu razvoja } \\
\text { višestaničnog organizma čime se } \\
\text { neposredno upućuje na očuvanje } \\
\text { stalnosti broja kromosoma. }\end{array}$ & $\begin{array}{l}\text { Mapa bi doprinijela nadogradnji } \\
\text { koncepta broja kromosoma u } \\
\text { tjelesnim/spolnim stanicama uz } \\
\text { uvjet da je dodatno naglašeno da } \\
\text { tjelesne stanice izgrađuju } \\
\text { autotrofne i heterotrofne } \\
\text { organizme, a spolne sudjeluju u } \\
\text { njihovom spolnom } \\
\text { razmnožavanju, što je u mapi } \\
\text { izostavljeno. }\end{array}$ & $\begin{array}{l}\text { Djelomično da. Dobro je vidljiva } \\
\text { usporedba broja kromosoma u } \\
\text { tjelesnim/spolnim stanicama. Bilo bi } \\
\text { dobro da je osim oznaka za broj } \\
\text { kromosoma naznačeno i da je riječ o } \\
\text { dvostrukom odnosno jednostrukom } \\
\text { broju kromosoma i povezano s } \\
\text { postojanjem/nepostojanjem } \\
\text { homolognih parova kromosoma. }\end{array}$ \\
\hline & \multirow[b]{2}{*}{ Razvoj biljaka } & $\checkmark$ & \pm & $\lambda$ \\
\hline & & $\begin{array}{c}\text { U mapi je } 2 n \text { broj kromosoma povezan s } \\
\text { nespolnom, a } n \text { broj kromosoma sa } \\
\text { spolnom generacijom. }\end{array}$ & $\begin{array}{l}\text { Mapa se mogla uspješno } \\
\text { iskoristiti za nadogradnju } \\
\text { usvojenih znanja o brojnosti } \\
\text { kromosoma da je na primjeru } \\
\text { spolne generacije mahovina } \\
\text { prikazano da nisu nužno } \\
\text { haploidne samo spolne stanice te } \\
\text { što uvjetuje } \\
\text { haploidnost/diploidnost, te bi je } \\
\text { bilo korisno nadograditi u tom } \\
\text { smjeru. }\end{array}$ & $\begin{array}{l}\text { Ne u većoj mjeri. Trebalo je bar na } \\
\text { primjeru mahovina koje su učenicima } \\
\text { najjednostavnije naglasiti da spora } \\
\text { nastaje mejozom i da ima haploidan } \\
\text { broj kromosoma te da se iz nje mitozom } \\
\text { razvija spolna generacija, kao i da će se } \\
\text { u tom slučaju gamete razviti mitozom } \\
\text { da bi se u njima očuvao haploidan broj } \\
\text { kromosoma. }\end{array}$ \\
\hline & \multirow[b]{2}{*}{$\begin{array}{l}\text { Srodnost, } \\
\text { raznolikost i } \\
\text { nasljeđivanje }\end{array}$} & $\checkmark$ & $\checkmark$ & \pm \\
\hline & & $\begin{array}{l}\text { U mapi je poveznicama detaljno prikazan } \\
\text { broj kromosoma u tjelesnim i spolnim } \\
\text { stanicama, kao i u oplođenoj jajnoj } \\
\text { stanici. Naglašene su i moguće } \\
\text { kombinacije spolnih kromosoma u } \\
\text { spolnim stanicama i oplođenoj jajnoj } \\
\text { stanici koje uvjetuju razvoj dječaka ili } \\
\text { djevojčice, čime je još zornije naznačena } \\
\text { diploidnost/haploidnost pojedine } \\
\text { stanice. }\end{array}$ & $\begin{array}{l}\text { Mapa omogućava nadogradnju } \\
\text { ranije usvojenih znanja jer je } \\
\text { zorno prikazana brojnost } \\
\text { kromosoma u različitim } \\
\text { stanicama, a koja je proširena } \\
\text { konceptima spolnih i tjelesnih } \\
\text { kromosoma. }\end{array}$ & $\begin{array}{l}\text { Velikim dijelom da. Mapa na primjeru } \\
\text { čovjeka prikazuje brojnost kromosoma } \\
\text { u tjelesnim/spolnim stanicama. Bilo bi je } \\
\text { dobro proširiti primjerima broja } \\
\text { kromosoma drugih vrsta da se provjeri } \\
\text { razumiju li učenici usvojeni obrazac, ali } \\
\text { to nije učinjeno jer je ključni koncept } \\
\text { koji proizlazi iz PiP-a i koji se želio u } \\
\text { mapi prikazati koncept ljudske } \\
\text { reprodukcije. }\end{array}$ \\
\hline
\end{tabular}




\begin{tabular}{|c|c|c|c|c|}
\hline \multirow{2}{*}{$\begin{array}{l}\text { Uočeni problemi } \\
\text { u razumijevanju }\end{array}$} & \multirow[b]{2}{*}{ Mapa } & \multicolumn{3}{|c|}{ OMOGUĆENO } \\
\hline & & POVEZANOST & KONCEPTUALNI RAZVOJ & $\begin{array}{l}\text { RAZRJEŠENJE PROBLEMA ILI } \\
\text { MISKONCEPCIJE }\end{array}$ \\
\hline \multirow{6}{*}{$\begin{array}{l}\text { Uloga procesa } \\
\text { mitoze/mejoze }\end{array}$} & \multirow[b]{2}{*}{$\begin{array}{c}\text { Od } \\
\text { najjednostavnijeg } \\
\text { oblika života do } \\
\text { stanice }\end{array}$} & $\checkmark$ & $\checkmark$ & \pm \\
\hline & & $\begin{array}{l}\text { U mapi je jasno prikazana povezanost } \\
\text { mitoze i mejoze s nastankom } \\
\text { tjelesnih/spolnih stanica, kao i njihova } \\
\text { uloga na razini organizma, } \\
\text { razmnožavanje jednostaničnih i rast } \\
\text { višestaničnih organizama. }\end{array}$ & $\begin{array}{l}\text { Mapa omogućava nadogradnju } \\
\text { koncepta uloge diobe kod } \\
\text { višestaničnih i jednostaničnih } \\
\text { organizama iz Prirode 5, a } \\
\text { dodatnu nadogradnju osigurava } \\
\text { povezanost ovih koncepata s } \\
\text { konceptima DNA i kromosoma iz } \\
\text { koje se neposredno može iščitati } \\
\text { način očuvanja stalnosti broja } \\
\text { kromosoma. }\end{array}$ & $\begin{array}{l}\text { Velikim dijelom da, jer je prikazana } \\
\text { njihova uloga i naglašeno da u proces } \\
\text { diobe mogu ući isključivo tjelesne } \\
\text { stanice. Mogla se još eventualno } \\
\text { temeljitije prikazati uloga ovih procesa u } \\
\text { očuvanju stalnosti broja kromosoma, } \\
\text { što bi svakako doprinijelo cjelovitijoj } \\
\text { izgradnji koncepta. }\end{array}$ \\
\hline & \multirow[b]{2}{*}{$\begin{array}{l}\text { Srodnost, } \\
\text { raznolikost i } \\
\text { nasljeđivanje }\end{array}$} & $\checkmark$ & \pm & \pm \\
\hline & & $\begin{array}{l}\text { U mapi je jasno prikazana povezanost } \\
\text { mitoze i mejoze s nastankom } \\
\text { tjelesnih/spolnih stanica čovjeka te } \\
\text { genska sličnost tjelesnih odnosno } \\
\text { različitost spolnih stanica. }\end{array}$ & $\begin{array}{l}\text { Mapa osigurava nadogradnju } \\
\text { koncepta uloge staničnih dioba } \\
\text { jer se nadovezuje na ranije } \\
\text { usvojena znanja, samo na } \\
\text { primjeru čovjeka. Mogla bi se } \\
\text { proširiti dodatnim poveznicima o } \\
\text { ulogama ovih procesa. }\end{array}$ & $\begin{array}{l}\text { Određenim dijelom da, ali ne u } \\
\text { potpunosti. Mapa dobro prikazuje } \\
\text { temeljene uloge mitoze i mejoze, ali bi } \\
\text { omogućila potpunije konceptualno } \\
\text { razumijevanje uloge ovih procesa da je } \\
\text { preciznije naglašena uloga mejoze u } \\
\text { genskoj raznolikosti potomaka. }\end{array}$ \\
\hline & \multirow[b]{2}{*}{$\begin{array}{l}\text { Sastav tijela, } \\
\text { razmnožavanje i } \\
\text { razvitak }\end{array}$} & $\checkmark$ & $\checkmark$ & \pm \\
\hline & & $\begin{array}{l}\text { U mapi je prikazana povezanost mitoze s } \\
\text { razvojem zametka i ploda kod čovjeka, } \\
\text { što je u skladu s nastavnom temom iz } \\
\text { PiP-a za čiju je sistematizaciju mapa } \\
\text { izrađena. }\end{array}$ & $\begin{array}{l}\text { Mapa osigurava nadogradnju } \\
\text { koncepta uloge mitoze u rastu } \\
\text { višestaničnog organizma. }\end{array}$ & $\begin{array}{l}\text { Određenim dijelom da. Bilo bi dobro da } \\
\text { je u mapu dodan i koncept tjelesne } \\
\text { stanice da se ukaže na izravnu vezu } \\
\text { između rasta zametka/ploda s } \\
\text { povećanjem broja tjelesnih stanica } \\
\text { procesom mitoze. }\end{array}$ \\
\hline \multirow{10}{*}{$\begin{array}{l}\text { Uloga procesa } \\
\text { oplodnje }\end{array}$} & \multirow[b]{2}{*}{$\begin{array}{l}\text { Od } \\
\text { najjednostavnijeg } \\
\text { oblika života do } \\
\text { stanice }\end{array}$} & $\checkmark$ & $\checkmark$ & \pm \\
\hline & & $\begin{array}{l}\text { U mapi je prikazana povezanost oplodnje } \\
\text { sa spajanjem spolnih stanica i nastankom } \\
\text { oplođene jajne stanice. Ǐčitavanjem } \\
\text { poveznica vidljiva je i povezanost } \\
\text { oplodnje s očuvanjem stalnosti broja } \\
\text { kromosoma, odnosno s nastankom } \\
\text { stanica s } 2 n \text { brojem kromosoma. }\end{array}$ & $\begin{array}{l}\text { Mapa omogućuje nadogradnju } \\
\text { koncepta uloge oplodnje iz } \\
\text { Prirode } 5 \text { te njegovo proširenje } \\
\text { koje je osigurano povezivanjem } \\
\text { koncepta oplodnje s konceptom } \\
\text { mejoze i očuvanja stalnosti broja } \\
\text { kromosoma. }\end{array}$ & $\begin{array}{l}\text { Djelomično da, ali ne u potpunosti. Nije } \\
\text { naglašeno da je oplodnja stapanje } \\
\text { jezgara jajne stanice i spermija te da u } \\
\text { skladu s tim oplođena jajna stanica } \\
\text { sadrži samo jezgru spermija, što je } \\
\text { preduvjet za konceptualno } \\
\text { razumijevanje principa majčinskog } \\
\text { nasljeđivanja (npr. mitohondrijske DNA) }\end{array}$ \\
\hline & \multirow[b]{2}{*}{$\begin{array}{c}\text { Razvoj } \\
\text { kralježnjaka }\end{array}$} & \pm & 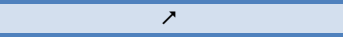 & $\lambda$ \\
\hline & & $\begin{array}{l}\text { U mapi je samo prikazana povezanost } \\
\text { spolnog razmnožavanja s mogućnošću } \\
\text { vanjske ili unutarnje oplodnje kod } \\
\text { različitih skupina kralježnjaka, ali ne i } \\
\text { uloga ovoga procesa. }\end{array}$ & $\begin{array}{c}\text { Mapa neznatno omogućuje } \\
\text { nadogradnju ranije usvojenih } \\
\text { znanja jer koncept nije razrađen } \\
\text { na razini primjene i } \\
\text { konceptualnog razumijevanja. } \\
\text { Trebalo je naglasiti prednosti i } \\
\text { nedostatke vanjske i unutarnje } \\
\text { oplodnje. }\end{array}$ & $\begin{array}{c}\text { Ne. U mapi nije prikazan proces } \\
\text { oplodnje, kao niti njegova uloga, već je } \\
\text { samo navedena konstatacija da postoje } \\
\text { dva različita načina oplodnje, ovisno o } \\
\text { uvjetima života. }\end{array}$ \\
\hline & \multirow[b]{2}{*}{ Razvoj biljaka } & $>$ & $\nearrow$ & $>$ \\
\hline & & $\begin{array}{l}\text { U mapi je djelomično prikazana uloga } \\
\text { oplodnje kod biljaka. Povezana je s } \\
\text { razvojem češera i ploda, ali nije dovoljno } \\
\text { jasno prikazana njezina uloga u } \\
\text { razmnožavanju mahovina i papratnjača. }\end{array}$ & $\begin{array}{l}\text { Mapa omogućuje nadogradnju } \\
\text { uspješnijim učenicima koji su } \\
\text { koncept oplodnje izgradili u toj } \\
\text { mjeri da će biti u mogućnosti } \\
\text { predvidjeti i sagledati i one } \\
\text { poveznice koje u mapi nisu } \\
\text { izravno navedene. }\end{array}$ & $\begin{array}{l}\text { Vjerojatno ne. Ukoliko učenik ne } \\
\text { razumije ulogu procesa oplodnje mapa } \\
\text { izrađena na prikazani način neće biti od } \\
\text { velike pomoći, jer zbog utjecaja PiP-a } \\
\text { nije naglašena njezina uloga, već se } \\
\text { pretpostavilo da su učenici koncept } \\
\text { oplodnje već izgradili. }\end{array}$ \\
\hline & \multirow[b]{2}{*}{$\begin{array}{l}\text { Srodnost, } \\
\text { raznolikost i } \\
\text { nasljeđivanje }\end{array}$} & $\checkmark$ & $\checkmark$ & \pm \\
\hline & & $\begin{array}{l}\text { U mapi je jasno prikazana povezanost } \\
\text { oplodnje sa spolnim razmnožavanjem i } \\
\text { spolnim stanicama čovjeka. Ǐčitavanjem } \\
\text { poveznica može se stvoriti jasna slika o } \\
\text { njezinoj povezanosti s očuvanjem } \\
\text { stalnosti broja kromosoma. }\end{array}$ & $\begin{array}{l}\text { Mapa omogućuje nadogradnju } \\
\text { koncepta uloge oplodnje iz } \\
\text { Prirode } 5 \text { i Biologije } 7 \text { te njegovo } \\
\text { proširenje koje je osigurano } \\
\text { povezivanjem koncepta oplodnje } \\
\text { s konceptom kromosoma i } \\
\text { razvojem dječaka ili djevojčice. }\end{array}$ & $\begin{array}{l}\text { U znatnoj mjeri da, ali ne u potpunosti. } \\
\text { Niti u ovoj mapi nisu navedeni pojmovi i } \\
\text { poveznice koji bi osigurali razumijevanje } \\
\text { principa majčinskog nasljeđivanja. }\end{array}$ \\
\hline & \multirow[b]{2}{*}{$\begin{array}{l}\text { Sastav tijela, } \\
\text { razmnožavanje i } \\
\text { razvitak }\end{array}$} & $\checkmark$ & \pm & \pm \\
\hline & & $\begin{array}{l}\text { U mapi su navedeni koncepti i poveznice } \\
\text { koji detaljno prikazuju ulogu oplodnje u } \\
\text { spolnom razmnožavanju čovjeka. } \\
\text { Oplodnja je povezana s plodnim danima, } \\
\text { trudnoćom i menstruacijskim ciklusom, } \\
\text { a naglašena je i uloga pojedinih spolnih } \\
\text { organa. }\end{array}$ & $\begin{array}{l}\text { Mapa omogućuje nadogradnju } \\
\text { koncepta oplodnje i } \\
\text { razmnožavanja na primjeru } \\
\text { čovjeka. Koncept oplodnje se još } \\
\text { eventualno mogao povezati s } \\
\text { konceptom mejoze da se utvrdi } \\
\text { ranije usvojeno znanje i stvori } \\
\text { cjelovita slika koncepta. }\end{array}$ & $\begin{array}{l}\text { U znatnoj mjeri da. Mapa sadrži podatke } \\
\text { o samom procesu oplodnje i njegovoj } \\
\text { ulozi. Naznačeno je da dolazi do } \\
\text { spajanja jezgara spolnih stanica, ali se } \\
\text { još trebalo naglasiti da ostali organeli } \\
\text { spermija propadaju što bi olakšalo } \\
\text { učenicima da razumiju povezanost } \\
\text { oplodnje s majčinskim nasljeđivanjem. }\end{array}$ \\
\hline
\end{tabular}

Od svih elemenata procjene mogućnosti razrješenja uočenih miskoncepcija većina mapa u kojima se trebaju ovi koncepti uključiti, ima dobru potporu u povezivanju predstavljenih pojmova, dok potpuno 
razrješenje problema i miskoncepcija nije podržano niti jednom mapom (tablica 2, slika 1). Konceptualni razvoj je najbolje podržan uz Ulogu procesa mitoze/mejoze, a najslabije je podržana Uloga procesa oplodnje, što u većoj mjeri učitelji i nastavnici nisu do sada uočavali kao veći problem u razumijevanju.

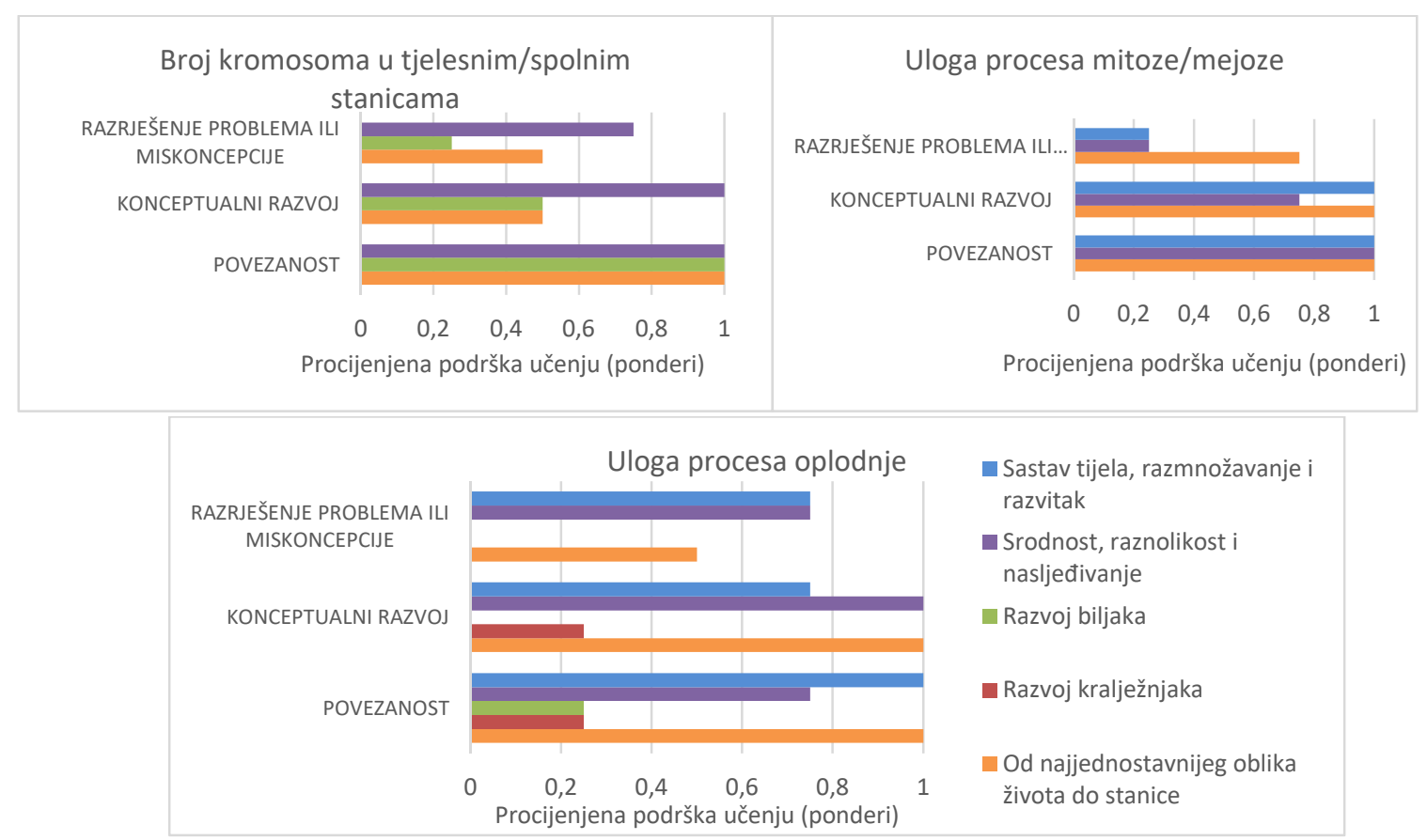

Slika 1 Omogućeno razrješenje uočenih problema pri učenju uz pravilnu upotrebu konceptualnih mapa (ponderi = 0 - ne, 0,25 - manjim dijelom, 0,5 - djelomično; 0,75, - većim dijelom; 1 - potpuno)

Ako se uzmu u obzir sve dostupne mape u svrhu potpore ostvarivanju konceptualnog razumijevanja učenika uz uočene probleme, povezanost važnih pojmova omogućena je u udjelu razrješenja od $82 \%$ (slika 2). Potpuni konceptualni razvoj za sve učenike korištenjem mapa omogućen je $s 45 \%$, a još 36 $\%$ prikaza podupire njegovo djelomično ostvarivanje (slika 2). S obzirom na ograničenja programa prema kojima su mape pripremane kao sistematizacija uz nastavne teme, uočeni problemi nisu u potpunosti podržani, iako omogućavaju 73 \% djelomično razrješenje uočenih problema da bi ostvarili uspješno učenje uz konceptualne mape kod svih učenika (slika 2).

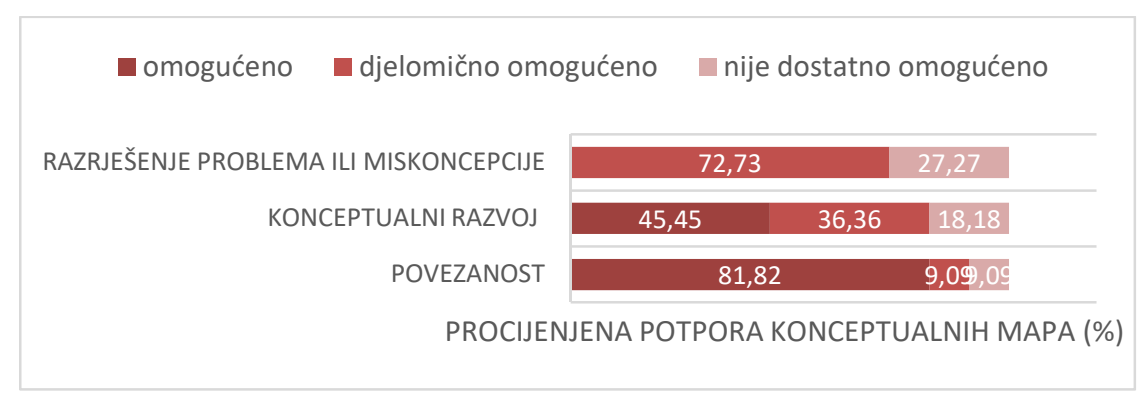

Slika 2 Udio ukupne potpore dostupnih konceptualnih mapa za razrješenje uočenih problema i miskoncepcija

Proučavajući ekspertne konceptualne mape koje su prilagođene nastavnim sadržajima propisanima Nastavnim planom i programom biologije, u svrhu da omoguće učenicima sistematizaciju usvojenih znanja, moguće je uočiti rascjepkanost koncepata u odgojno-obrazovnoj vertikali. Tijekom svake godine poučavanja Prirode/Biologije učenici dobivaju polovične informacije o pojedinim konceptima u različitim kontekstima što otežava izgradnju temeljnih bioloških koncepata. Vidljivo je da i same mape 
ne sadrže sve poveznice važne za izgradnju koncepta što je djelomično uvjetovano ograničenošću prostora, ali svakako i važećim PiP-om. Nepostojanje cjelovite slike koncepata otežava učenicima primjenu usvojenih znanja i potiče reprodukciju što ukazuje na važnost promjene u organizaciji nastavnih sadržaja Prirode/Biologije, kojoj se pristupilo izradom kurikuluma nastavnih predmeta. Konceptualni okvir kurikuluma Biologije, koji je osigurao konceptualni pristup učenju i poučavanju, podrazumijevao je i da mapa za sistematizaciju obrađenih tema sadrži pojmove i poveznice koji omogućuju izgradnju koncepta Razmnožavanje i razvoj organizama. Vidljivi su manji nedostaci u važnim pojmovima i poveznicama u mapi što je prvenstveno uvjetovana širinom koncepta i ograničenošću prostora, s obzirom da je konceptualna mapa ponuđena učenicima za sistematizaciju znanja u radnoj bilježnici (tablica 3).

Tablica 3 Analiza mogućnosti potpore u učenju i razrješavanju uočenih problema u razumijevanju u ekspertnoj mapi iz radne bilježnice (Begić i sur, 2019) uz udžbenike biologije za 8. razred prema kurikulumu

\begin{tabular}{|c|c|c|c|c|}
\hline \multirow{2}{*}{$\begin{array}{l}\text { Uočeni problemi u } \\
\text { razumijevanju }\end{array}$} & \multirow{2}{*}{ Mapa } & \multicolumn{3}{|c|}{ OMOGUĆENO } \\
\hline & & POVEZANOST & KONCEPTUALNI RAZVOJ & $\begin{array}{l}\text { RAZRJEŠENJE PROBLEMA ILI } \\
\text { MISKONCEPCIJE }\end{array}$ \\
\hline \multirow[b]{2}{*}{$\begin{array}{c}\text { Broj kromosoma u } \\
\text { tjelesnim/spolnim } \\
\text { stanicama }\end{array}$} & \multirow{6}{*}{$\begin{array}{l}\text { Razmnožavanje } \\
\text { u ulozi održivosti } \\
\text { života }\end{array}$} & $\checkmark$ & $\checkmark$ & $\checkmark$ \\
\hline & & $\begin{array}{l}\text { U mapi je uporabom oznaka ( } 2 n \text { i } \\
n \text { ) naglašen broj kromosoma u } \\
\text { tjelesnim i spolnim stanicama, } \\
\text { kao i u oplođenoj jajnoj stanici, } \\
\text { za koju je prikazano da se dalje } \\
\text { dijeli mitozom u svrhu razvoja } \\
\text { višestaničnog organizma čime se } \\
\text { neposredno upućuje na očuvanje } \\
\text { stalnosti broja kromosoma. U } \\
\text { mapi je prikazano i da mitoza ima } \\
\text { ulogu u razmnožavanju } \\
\text { jednostaničnih organizama čime } \\
\text { je dodatno ukazano na očuvanje } \\
\text { stalnosti broja kromosoma. }\end{array}$ & $\begin{array}{l}\text { U mapi je prikazano da tjelesne } \\
\text { stanice izgrađuju tijelo, a spolne } \\
\text { sudjeluju u spolnom } \\
\text { razmnožavanju što pridonosi } \\
\text { konceptualnom razumijevanju } \\
\text { očuvanja stalnosti broja } \\
\text { kromosoma. Također, ukazano je } \\
\text { na povezanost mitoze s } \\
\text { nespolnim razmnožavanjem } \\
\text { jednostaničnih organizama što } \\
\text { dodatno doprinosi razumijevanju } \\
\text { očuvanja stalnosti broja } \\
\text { kromosoma. }\end{array}$ & $\begin{array}{l}\text { Da. Dobro je vidljiva usporedba } \\
\text { broja kromosoma u } \\
\text { tjelesnim/spolnim stanicama. } \\
\text { Naznačeno je da broj } n \text { predstavlja } \\
\text { polovičnu, a } 2 n \text { potpunu nasljednu } \\
\text { uputu. Također je naznačeno da se } \\
\text { replikacija zbiva prije diobe te da je } \\
\text { koromosom nakon replikacije } \\
\text { građen od dvije, a nakon diobe od } \\
\text { jedne kromatide što dodatno } \\
\text { pridonosi razumijevanju principa } \\
\text { očuvanja stalnosti broja } \\
\text { kromosoma. Ono što također može } \\
\text { pridonijeti razumijevanju principa } \\
\text { očuvanja stalnosti broja } \\
\text { kromosoma jeste što mapa } \\
\text { prikazuje koncept razmnožavanja i } \\
\text { nasljeđivanja kod biljaka, životinja i } \\
\text { jednostaničnih organizama } \\
\text { ukazujući na sličnosti i razlike. }\end{array}$ \\
\hline \multirow[b]{2}{*}{$\begin{array}{l}\text { Uloga procesa } \\
\text { mitoze/mejoze }\end{array}$} & & $\checkmark$ & $\checkmark$ & \pm \\
\hline & & $\begin{array}{l}\text { U mapi je prikazana povezanost } \\
\text { mitoze s razvojem zametka i } \\
\text { ploda kod životinja i biljaka te s } \\
\text { razmnožavanjem jednostaničnih } \\
\text { organizama, kao i povezanost } \\
\text { mejoze s nastankom spolnih } \\
\text { stanica. }\end{array}$ & $\begin{array}{l}\text { Mapa omogućava izgradnju } \\
\text { koncepta uloga procesa mitoze } \\
\text { kod višestaničnih i jednostaničnih } \\
\text { organizama, kao i ulogu procesa } \\
\text { mejoze kod višestaničnih } \\
\text { organizama. Također, mapa } \\
\text { osigurava i dodatnu nadogradnju } \\
\text { ovih koncepata jer prikazuje } \\
\text { njihovu povezanost s konceptima } \\
\text { DNA, replikacija i kromosomi, a iz } \\
\text { čega se neposredno iščitava i } \\
\text { princip očuvanja stalnosti broja } \\
\text { kromosoma. }\end{array}$ & $\begin{array}{l}\text { Najvećim dijelom da, jer je } \\
\text { prikazana njihova uloga u } \\
\text { razmnožavanju i rastu živih bića. } \\
\text { Uključen je i koncept tjelesna } \\
\text { stanica čime se indirektno stvara } \\
\text { veza mitoze s povećanjem broja } \\
\text { tjelesnih stanica i rastom } \\
\text { zametka/ploda, a time i organizma. } \\
\text { Ono što u mapi nedostaje je prikaz } \\
\text { povezanosti mitoze s regeneracijom } \\
\text { tijela višestaničnih organizama. }\end{array}$ \\
\hline \multirow[b]{2}{*}{$\begin{array}{l}\text { Uloga procesa } \\
\text { oplodnje }\end{array}$} & & $\checkmark$ & \pm & \pm \\
\hline & & $\begin{array}{l}\text { U mapi je jasno prikazana } \\
\text { povezanost oplodnje sa spolnim } \\
\text { razmnožavanjem kako životinja } \\
\text { tako i biljaka te je ukazano da } \\
\text { ona nije obilježje nespolnog } \\
\text { razmnožavanja. Nadalje, } \\
\text { iščitavanjem poveznica može se } \\
\text { stvoriti jasna slika o njezinoj } \\
\text { povezanosti s očuvanjem } \\
\text { stalnosti broja kromosoma, a } \\
\text { istaknuta je i njezina povezanost } \\
\text { s menstruacijom i ovulacijom. }\end{array}$ & $\begin{array}{l}\text { Većim dijelom da. Prikazana } \\
\text { povezanost oplodnje s } \\
\text { genetskom varijabilnošću, kao i } \\
\text { nedostaci samooplodnje. } \\
\text { Navedena je razlika između } \\
\text { vanjske i unutarnje oplodnje, ali } \\
\text { bi bilo dobro da su prikazane i } \\
\text { njihove prednosti i nedostaci, } \\
\text { iako se indirektno može iščitati } \\
\text { prednost oplodnje bez vode na } \\
\text { primjeru kritosjemenjača. } \\
\text { Također, konceptualnom } \\
\text { razumijevanju pridonosi i } \\
\text { povezanost koncepta oplodnje s } \\
\text { konceptom očuvanja stalnosti } \\
\text { broja kromosoma. }\end{array}$ & $\begin{array}{l}\text { Većim dijelom da. Naglašeno je da } \\
\text { je oplodnja stapanje jezgara jajne } \\
\text { stanice i spermija, a na temelju } \\
\text { čega je indirektno moguće zaključiti } \\
\text { da oplođena jajna stanica sadrži } \\
\text { samo jezgru spermija, što je } \\
\text { preduvjet za razumijevanje principa } \\
\text { majčinskog nasljeđivanja. Ipak, bilo } \\
\text { bi bolje da su u mapu uključeni } \\
\text { pojmovi i poveznice koje jasnije } \\
\text { ukazuju na povezanost procesa } \\
\text { oplodnje s majčinskim } \\
\text { nasljeđivanjem. }\end{array}$ \\
\hline
\end{tabular}


Konceptualna mapa koja je pripremljena prema kurikulumu Biologije podržava izgradnju koncepta Razmnožavanje i velikim dijelom omogućava razrješenja analiziranih miskoncepcija (tablica 3). Mapa osigurava potpunu potporu povezivanju predstavljenih pojmova, iako postoji mogućnost njenog proširenja dodatnim pojmovima i poveznicama što bi svakako pridonijelo učinkovitijem konceptualnom razvoju. Povezanost pojmova neophodnih za razumijevanje koncepta Razmnožavanje u osnovnoj školi omogućena je u udjelu od 95 \% (slika 3). Konceptualno razumijevanje procesa razmnožavanja korištenjem konceptualne mape Razmnožavanje u ulozi održivosti života omogućeno je učenicima s udjelom $87 \%$. Slabije su vrijednosti procjene razumljivosti mape na osnovu korištenih riječi povezivanja (77 \%), a tome je razlog da korišten oblik riječi ne daje uvijek odmah rečenice u poveznici s pripadajućim pojmovima, već treba malo razmišljati i uklopiti gramatičke konstrukcije pri interpretaciji (slika 3). Mapa pruža potpunu potporu za sprječavanje nastanka miskoncepcije Broj kromosoma u tjelesnim/spolnim stanicama. Miskoncepcija Uloga procesa mitoze/mejoze podržana je za učenje s procijenjenih $85 \%$, a miskoncepcija Uloga procesa oplodnje uz pravilno korištenje mape treba biti razriješena s $84 \%$.

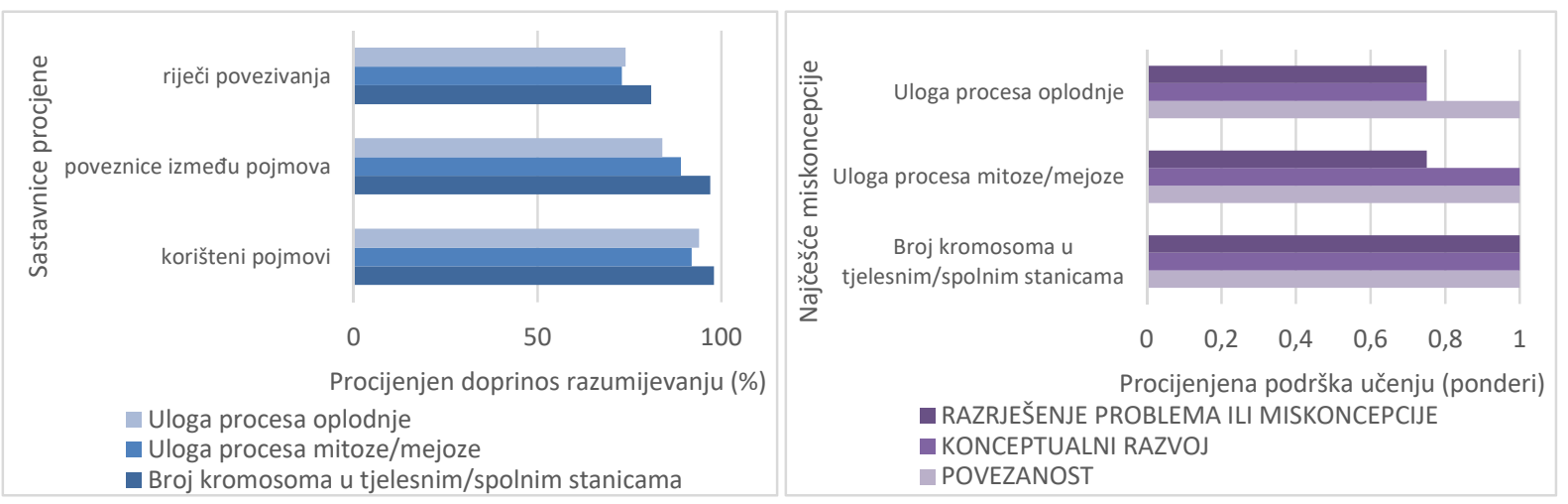

Slika 3 Omogućeno razrješenje uočenih problema pri učenju uz pravilnu upotrebu konceptualne mape Razmnožavanje u ulozi održivosti života (ponderi = 0 - ne, 0,25 - manjim dijelom, 0,5 - djelomično; 0,75, - većim dijelom; 1 - potpuno)

\section{RASPRAVA}

Dosadašnji Nastavni programi prirode i biologije u hrvatskim školama pretežno su sadržajno orijentirani, a sadržaji su vezani uz podjelu biologije prema područjima (Radanović i sur, 2010). Slično se može vidjeti i u organizaciji nastave biologije u drugim zemljama, gdje se biologija uči na osnovu pamćenja činjenica bez njihova međusobnog povezivanja (Din Yan Yip, 1998). Tek se unatrag nekoliko godina može pronaći reorganizacija nastavnih sadržaja biologije prema konceptima, npr. u ispitnom katalogu državne mature, gdje se obrazovni ishodi organiziraju prema konceptima koje ispituju te se na taj način tvore konceptualne poveznice između nastavnih tema. $U$ samom načinu učenja $i$ poučavanja biologije, nalazimo probleme jer hrvatski učitelji i nastavnici nemaju dovoljan uvid u stvarno konceptualno razumijevanje učenika (Lukša, 2013b), pa ne mogu ispravno odrediti predkoncepcije i očekivane miskoncepcije, čije bi poznavanje bilo vrlo korisno u planiranju nastave.

Za razvoj konceptualnog razumijevanja bioloških sadržaja, nastava biologije trebala bi biti vođena izgradnjom koncepata što se lakše postiže upotrebom novijih nastavnih strategija u usporedbi $s$ tradicionalnom, predavačkom nastavom. Suvremena nastava trebala bi biti konstruktivistička, gdje učenik svojom aktivnošću može izgraditi svoje znanje na dubljoj razini već u učionici. U tu svrhu, kod izgradnje konceptualnog razumijevanja predlaže se korištenje konceptualnih mapa. Konceptualne mape koristan su alat čijom se primjenom u nastavi kod učenika pospješuje retencija znanja, ali i bolji 
rezultati u rješavanju pitanja viših kognitivnih razina (Latin i sur., 2016). Učenici koji u nastavi koriste konceptualne mape samostalno uče, povezuju pojmove i kritički razmišljaju, što pridonosi njihovom kasnijem uspjehu pri rješavanju zadataka viših kognitivnih razina (Latin i sur, 2016; Adamov i sur, 2009, Yip, 1998). Učenici koji tijekom učenja izrađuju konceptualne mape uspješniji su u prepoznavanju veza između koncepata (Radanović i sur, 2017c).

Samostalno učenje na osnovu pripremljenih ekspertnih konceptualnih mapa ili njihova površna demonstracija bez dobre potpore i objašnjenja predstavljenih koncepata, ne donosi boljem razumijevanju u odnosu na kvalitetno poučavanje bez njihove primjene, štoviše, neadekvatna primjena konceptualnih mapa, može učenike više zbuniti nego što im olakšava razumijevanje (Radanović i sur, 2017c). Kontinuirano poučavanje uz primjenu konceptualnih mapa podrazumijeva njihovu početnu demonstraciju u kojoj će učitelji i nastavnici na primjeru postojećih ekspertnih mapa ili samostalno izrađenih mapa učenicima ispričati i povezati sve predočene koncepte u smislenu i lako razumljivu priču. Vrlo je važno da se kod njezine demonstracije objasne poveznice između pojmova i razriješe uočene miskoncepcije. Nakon takve kvalitetne pripreme treba učenicima omogućiti vježbanje uz popunjavanje predloška i samostalnu izradu mapa u kojima će primijeniti svoje znanje. Zaključak da korištenje konceptualnih mapa pri učenju pridonosi boljem razumijevanju potvrđuju i prethodna istraživanja (Radanović i sur, 2017c) prema kojem su jedino učenici koji su kvalitetno kontinuirano poučavani uz konceptualne mape uspješno usvojili koncepte predviđene ishodima propisanih dokumenata.

Uz neke udžbenike biologije u Hrvatskoj dostupne su konceptualne mape, odnosno njihovi predlošci koje učenik treba dopuniti prilikom učenja i tako samostalno graditi konceptualno razumijevanje nastavnih sadržaja. Te su konceptualne mape alat za učenje, ali mogu biti i alat za vrednovanje znanja, jer se kroz njihovo ispunjavanje mogu ispitati brojni obrazovni ishodi propisani Nastavnim planom i programom za osnovnu školu (MZOŠ, 2006). Osim popunjavanja predloška konceptualnih mapa, učiteljima biologije predlaže se i poučavanje učenika izradi konceptualnih mapa, kojima se također može vrednovati znanje učenika. Konceptualne mape u nastavi dobro su pomagalo za ostvarivanje konceptualnog razumijevanja, a mogu poslužiti i u ranom otkrivanju miskoncepcija učenika.

Postoji problem kod povezivanja staničnih dioba i nasljeđivanja, jer učenici ne povezuju kromosome i molekule DNA (Lukša, 2011, Šorgo i Šiling, 2017). Za uspješnu izgradnju temeljnih koncepata, ključni bi se koncepti trebali međusobno povezivati, nadopunjavati i izgrađivati kroz više godina u tijeku osnovnoškolskog i srednjoškolskog obrazovanja, što bi se čak i u dosadašnjoj organizaciji sadržaja biologije u nastavi moglo ostvariti primjenom modela kumulativnog učenja (Gagné, 1958). U slaganju s Garašić i sur. (2013), rezultati ovog rada ukazuju na potrebu promjene načina rada u nastavi biologije u hrvatskim školama uključivanjem strategija aktivnog učenja.

Rezultati o miskoncepcijama unutar koncepta Razmnožavanje (Lukša i sur, 2016; Golubić i sur, 2017) mogu pomoći pri uvidu u česte probleme u učenju i poučavanju sadržaja uz makrokoncept Razmnožavanje i razvoj organizma te otklanjanje miskoncepcija koje se iznova utvrđuju na uzorku učenika hrvatskih osnovnih škola. Proučavajući ekspertne konceptualne mape koje su prilagođene nastavnim sadržajima propisanima Nastavnim planom i programom biologije, u svrhu da omoguće učenicima sistematizaciju usvojenih znanja, moguće je uočiti rascjepkanost koncepata u odgojnoobrazovnoj vertikali. Tijekom svake godine poučavanja Prirode/Biologije učenici dobivaju polovične 
informacije o pojedinim konceptima u različitim kontekstima što otežava izgradnju temeljnih bioloških koncepata. Vidljivo je da i same mape ne sadrže sve poveznice važne za izgradnju koncepta što je djelomično uvjetovano ograničenošću prostora, ali svakako i važećim PiP-om. Nepostojanje cjelovite slike koncepata otežava učenicima primjenu usvojenih znanja i potiče reprodukciju što ukazuje na važnost promjene u organizaciji nastavnih sadržaja Prirode/Biologije, kojoj se pristupilo izradom kurikuluma nastavnih predmeta. Konceptualni okvir kurikuluma nastavnog premeta Biologija, koji je osigurao konceptualni pristup učenju i poučavanju, podrazumijevao je i da mapa za sistematizaciju obrađenih nastavnih tema sadrži pojmove i poveznice koji omogućuju izgradnju koncepta Razmnožavanje i razvoj organizama. Vidljivi su manji nedostaci u važnim pojmovima i poveznicama u mapi što je prvenstveno uvjetovana širinom koncepta i ograničenošću prostora, s obzirom da je konceptualna mapa ponuđena učenicima za sistematizaciju znanja u radnoj bilježnici. Usprkos toga, konceptuana mapa Razmnožavanje u ulozi održivosti života omogućava razrješenje uočenih problema u učenju i poučavanju te miskoncepcija ako se učenje uz konceptualne mape dobro pripremi i podrži.

\section{ZAKLUČAK I METODIČKI ZNAČAJ}

Konceptualne mape koristan su alat za poučavanje i vrednovanje znanja, kojima se može pospješiti izgradnja koncepata i uviđanje konceptualnih poveznica te provjeriti ostvarenost obrazovnih postignuća. Izrada konceptualne mape u nastavi biologije jedna je od metoda aktivnog uključivanja učenika u nastavni proces čime bi se pozitivno utjecalo na izgradnju konceptualnog razumijevanja i razvijanja znanja na višim kognitivnim razinama kod svakog učenika, što je, sudeći prema rezultatima istraživanja, nužno za razumijevanje biologije.

Tijekom nastave učenici često izrađuju modele staničnih dioba bez povezivanja tih procesa $\mathrm{s}$ odgovarajućim primjerima zbivanja u organizmu. Bilo bi dobro kada bi se dinamični modeli izrađivali na način da se u istom prikazu poveže nastanak spolnih stanica mejozom, oplodnja i nastanak zigote, te dalje mitoza tjelesnih stanica u svrhu rasta i razvoja organizma. Također bi bilo dobro tražiti učenike da te procese prikazuju crtežima, stripovima ili stop animacijom u kontekstu životnih ciklusa različitih organizama, stanica i tkiva. Općenito, u nastavi se životni ciklusi organizama uglavnom promatraju samo makroskopski, pa učenici teže povezuju naučene životne cikluse sa zbivanjima na razini stanice. Osim korištenja modela, interaktivne igre, u kojima bi učenici mogli određivati tijek opisanih ciklusa te vidjeti kakvo bi značenje njihove pogreške imale za živu stanicu ili organizam, bile bi korisno pomagalo pri povezivanju nastavnih sadržaja i uspostavi uzročno-posljedičnih veza, procesa i pojava. Tijekom poučavanja mejoze, posebno na razini osnovne škole zbog pojednostavljenja, često se smatra dostatnim prikazivanje dvije kopije gena u dvije različite boje, bez posebnog naglašavanja $i$ pojašnjavanja uloge boja u prikazu. Stoga učenici zanemaruju važnost nasljeđivanja DNA i gena od dva roditelja, zbog čega u tjelesnim stanicama mogu postojati dvije kopije gena, dok se zbog raspodjele kromosoma tijekom nastanka spolnih stanica broj kopija smanji na jednu.

Dostupna konceptualna mapa koja objašnjava važnost procesa razmnožavanja za održivost života na Zemlji odnosno opstanak vrste, pripremljena za učenike 8. razreda osnovne škole, podržava izgradnju koncepta Razmnožavanje i omogućava razrješenje najčešće uočenih miskoncepcija (Broj kromosoma u tjelesnim/spolnim stanicama, Uloga procesa mitoze/mejoze, Uloga procesa oplodnje). Bilo bi poželjno da učenici izrađenu konceptualnu mapu prošire dodatnim pojmovima i poveznicama kako bi se postigla veća širina i dubina konceptualnog razumijevanja i umrežavanje znanja. 


\section{LITERATURA}

Adamov, J., Segedinac, M., Cvjetičanin, S., Bakos, R. (2009). Concept maps as diagnostic tools in assessing the acquisition and retention of knowledge in biochemistry. Odgojne znanosti, 1, 53-71.

Barker, M., Carr, M. (1989). Photosynthesis: can our pupils see the wood for the trees? Journal of Biological Education: 23 (1): 41-44

Bastić, M., Begić, V., Novoselić, D., Popović, M. (2014). Biologija 8, udžbenik iz biologije za osmi razred osnovne škole, Alfa, Zagreb

Begić, V., Madaj Prpić, J., Novoselić, D. (2014). Biologija 7, udžbenik iz biologije za sedmi razred osnovne škole, Alfa, Zagreb

Begić, V., Bastić, M., Madaj Prpić, J., Bakarić, A. (2019). Biologija 8, udžbenik iz biologije za osmi razred osnovne škole

(eksperimentalna provedba kurikularne reforme), Alfa, Zagreb

Begić, V., Bastić, M., Madaj Prpić, J., Bakarić, A. (2019). Biologija 8, radna bilježnica iz biologije za osmi razred osnovne škole (eksperimentalna provedba kurikularne reforme), Alfa, Zagreb

Begić, V., Bastić, M., Radanović, I. (2016). Utjecaj biološkog znanja učenika na rješavanje zadataka viših kognitivnih razina. Educ. biol., 2:13-42.

Bransford, J. D., Brown, A.L.,Cocking, R.R. (2000). How People Learn: Brain, Mind, Experience and School. Washington D.C.: National Academy Press: 3-23.

Costa, A. L. (1985). Teacher behaviors that enable student thinking. In A.L. Costa (Ed.), Developing minds: A resource book for teaching thinking, Alexandria, Association for Supervision and Curriculum Development, 125-137.

Crooks, T.J. (1988). The Impact Of Classroom Evaluation Practices On Students, Review of Educational Research, 58 (4): $438-$ 481

Fisher, K. (1985). A Misconception in Biology: Amino Acids and Translation. Journal Of Research In Science Teaching, Vol.22, 53-62.

Garašić, D, Radanović, I., Lukša, Ž. (2013). Usvojenost makrokoncepata biologije tijekom učenja u osnovnoj školi i gimnaziji. Metodike u suvremenom odgojno-obrazovnom sustavu, Milanović, D., Bežen, A., Domović, V. (ur.). Akademija odgojno-obrazovnih znanosti Hrvatske, Zagreb, str. 211-239.

Garašić, D. (2012). Primjerenost biološkog obrazovanja tijekom osnovnog i gimnazijskog školovanja: doktorska disertacija Prirodoslovno-matematički fakultet Sveučilišta u Zagrebu. 348 str.

Glynn, S.M., Duit, R. (1995). Learning science meaningfully: Constructing cenceptual models. In S.M. Glynn \& R. Duit (Eds.), Learning science in the schools: Research reforming practice. New Jersey: Lawrence Erlbaum Associates. 3-33

Golubić, M., Begić, V., Lukša, Ž., Korać, P., Radanović, I. (2017). Razumijevanje životnog ciklusa i oplodnje tijekom učenja biologije u osnovnoj školi. Educ. biol. 3, 1, 76-99.

Kinchin, I. M., Hay, D. B. (2000). How a qualitative approach to concept map analysis can be used to aid learning by illustrating patterns of conceptual development. Educational Research 42, 1, 43-57

Krathwohl, D. R. (2002). A Revision of Bloom's Taxonomy: An Overview. Theory into practice, 41, 212-218.

Latin, K., Merdić, E., Labak, I. (2016). Usvojenost nastavnog sadržaja iz biologije primjenom konceptualnih mapa kod učenika srednje škole. Educ. biol., 2:1-9.

Lorenzo, M., Crouch, C.H., Mazur,E. (2006). Reducing the gender gap in the physics classroom. Am J Phys 74: 118-122, doi: 10.1152/advan.00061.2005. preuzeto 1.4.2017.

Lukša, Ž. (2011). Učeničko razumijevanje i usvojenost osnovnih koncepata u biologiji: doktorska disertacija. Prirodoslovnomatematički fakultet Sveučilišta u Zagrebu. 317. str.

Lukša, Ž., Radanović, I., Garašić, D. (2013a). Konceptualni pristup poučavanju uz definiranje makrokonceptualnog okvira za biologiju, Život i škola, br. 30 (2): 156-171.

Lukša Ž., Radanović, I., Garašić, D. (2013b). Očekivane i stvarne miskoncepcije učenika u biologiji. Napredak: časopis za pedagogijsku teoriju i praksu. 154(4): 527-548.

Lukša, Ž., Radanović, I., Garašić, D., Sertić Perić, M. (2016). Misconceptions of Primary and High School Students Related to the Biological Concept of Human Reproduction, Cell Life Cycle and Molecular Basis of Heredity. Journal of Turkish Science Education (TUSED). 13(3): 143-160.

Mestre, J. (2001). Cognitive aspects of learning and teaching. National Science Foundation (NSF), 80-94.

Momsen, J.L., Long, T.M., Wyse, S.A., Ebert-May, D. (2010). Just the Facts? Introductory Undergraduate Biology Courses Focus on Low-Level Cognitive SkillsCBE-Life Sciences Education. Vol. 9: 435-440

MZO (2017). Nacionalni dokument Prirodoslovnog područja kurikuluma - prijedlog nakon javne rasprave, Ministarstvo znanosti i obrazovanja,

https://mzo.gov.hr/UserDocsImages//dokumenti/Obrazovanje/NacionalniKurikulum/PodrucjaKurikuluma//Prirodoslovno\%20podru\%C4\%8Dje .pdf, preuzeto 17.2.2020.

MZO (2019). Kurikulum nastavnog predmeta Biologija za osnovne i srednje škole, Ministarstvo znanosti i obrazovanja, NN 7/19, https://narodne-novine.nn.hr/clanci/sluzbeni/2019 017 149.html, preuzeto 17.1.2020.

MZOŠ (2006). Nastavni plan i program za osnovnu školu. Ministarstvo znanosti, obrazovanja i sporta Zagreb. Nakladnik Dragan Primorac, urednici Dijana Vican i Ivan Milanović Litre.

Novak, J. D., Cañas, A. J. (2008). The Theory Underlying Concept Maps and How to Construct and Use Them, Technical report IHMC CmapTools 2006-01 Rev 01-2008, Florida Institute for Human and Machine Cognition, 2008. 
Radanović, I., Ćurković, N., Bastić, M., Leniček, S., Furlan, Z., Španović, P. \& Valjak, M. (2010). Kvalitativna analiza ispita provedenih 2008. godine u osnovnim školama, Izvješće o projektu - Biologija, Nacionalni centar za vanjsko vrednovanje, Zagreb.

Radanović, I., Garašić, D., Lukša, Ž., Pongrac Štimac, Z., Bastić M., Kapov S., Karakaš D., Lugarić S., Vidović M. (2015). Ispitni katalog za Državnu maturu iz Biologije. NCVVO, Zagreb. 53 str.

Radanović I., Lukša Ž., Begić V., Bastić M., Gotlibović G., Kapov S., Pavunec S., Toljan M. (2017a). Sadržajna i metodološka analiza ispita državne mature iz Biologije školskih godina 2013./2014. i 2014./2015. NCVVO Zagreb, 101 str.

Radanović, I., Lukša, Ž., Pongrac Štimac, Z., Garašić, D., Bastić, M., Kapov, S., Kostanić, LJ., Sertić Perić, M., Toljan, M. (2017b). Sadržajna i metodološka analiza ispita državne mature iz Biologije u školskoj godini 2015./2016. NCVVO Zagreb, 212 str.

Radanović,I., Lukša, Ž., Garašić, D., Sertić Perić, M., Gavric, B., Begić, V., Novoselic, D. (2017c). The effect of learning experiences using expert concept maps on understanding cell division processes..- ESERA (European Science Education Researche Association), Dublin. Ireland.

Ruiz-Primo, M., Schultz, S., Li, M., \& Shavelson, R. (2001). Comparison of the reliability and validity of scores from two concept-mapping techniques. Journal of Research in Science Teachinf 38, 260-278.

Šorgo, A., Šiling, R. (2017). Fragmented Knowledge and Missing Connections between Knowledge from Different Hierarchical Organisational Levels of Reproduction among Adolescents and Young Adults, Center for Educational Policy Studies Journal, v7 n1: 69-91.

Wood, W.B. (2009). Revising the AP biology curriculum. Science 325: 1627-1628

Yaman S. (2017). Investigating Consistency of Questions in Primary and Middle School Science Textbooks with Objectives in Science Curriculum. Journal of Education and Training Studies, 5, 4, 81-89.

\section{PRILOZI}

Prilog 1 Konceptualna mapa za sistematizaciju nastavne teme Od najjednostavnijeg oblika života do stanice

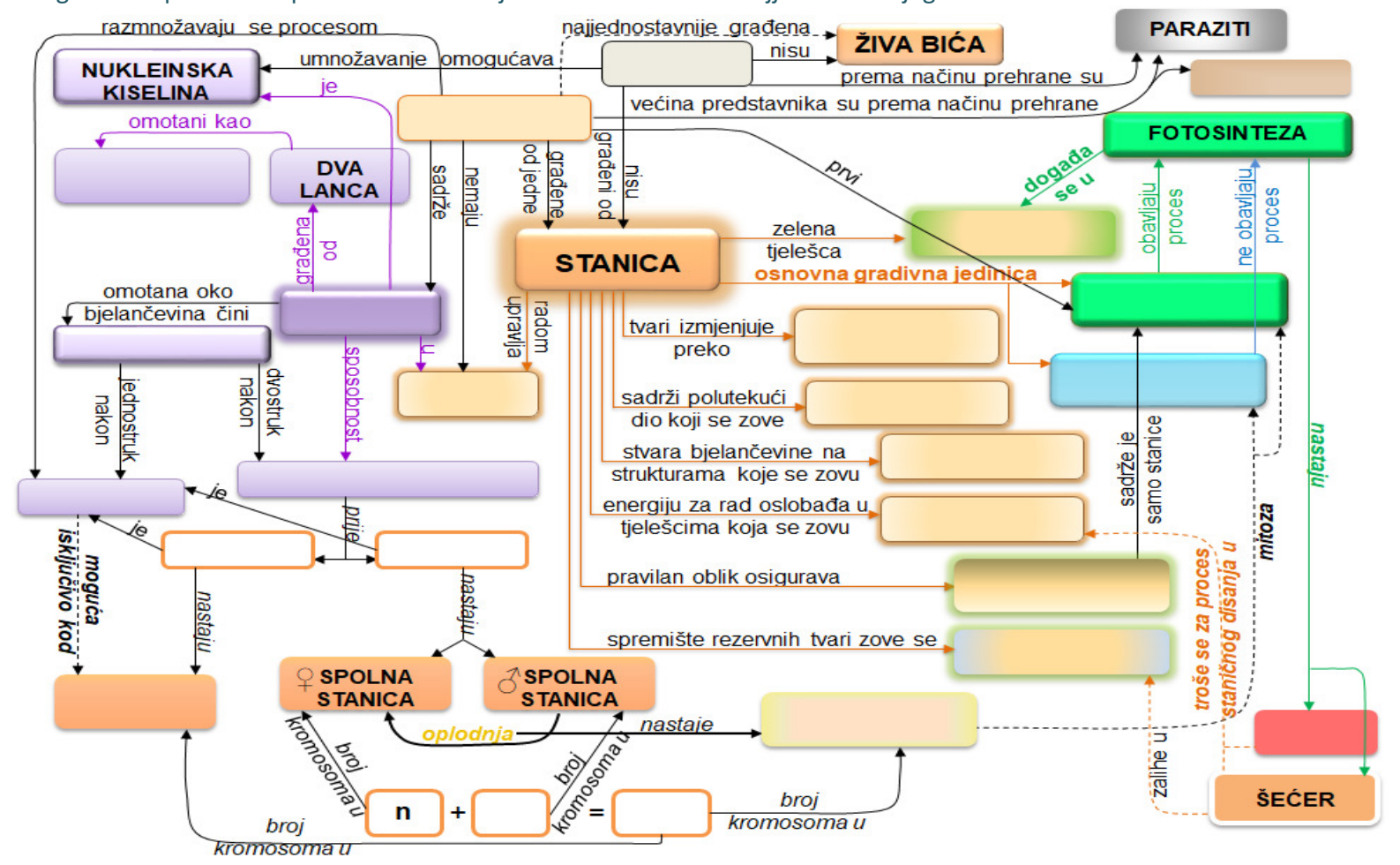


Prilog 2 Konceptualna mapa za sistematizaciju nastavne teme Razvoj kralježnjaka

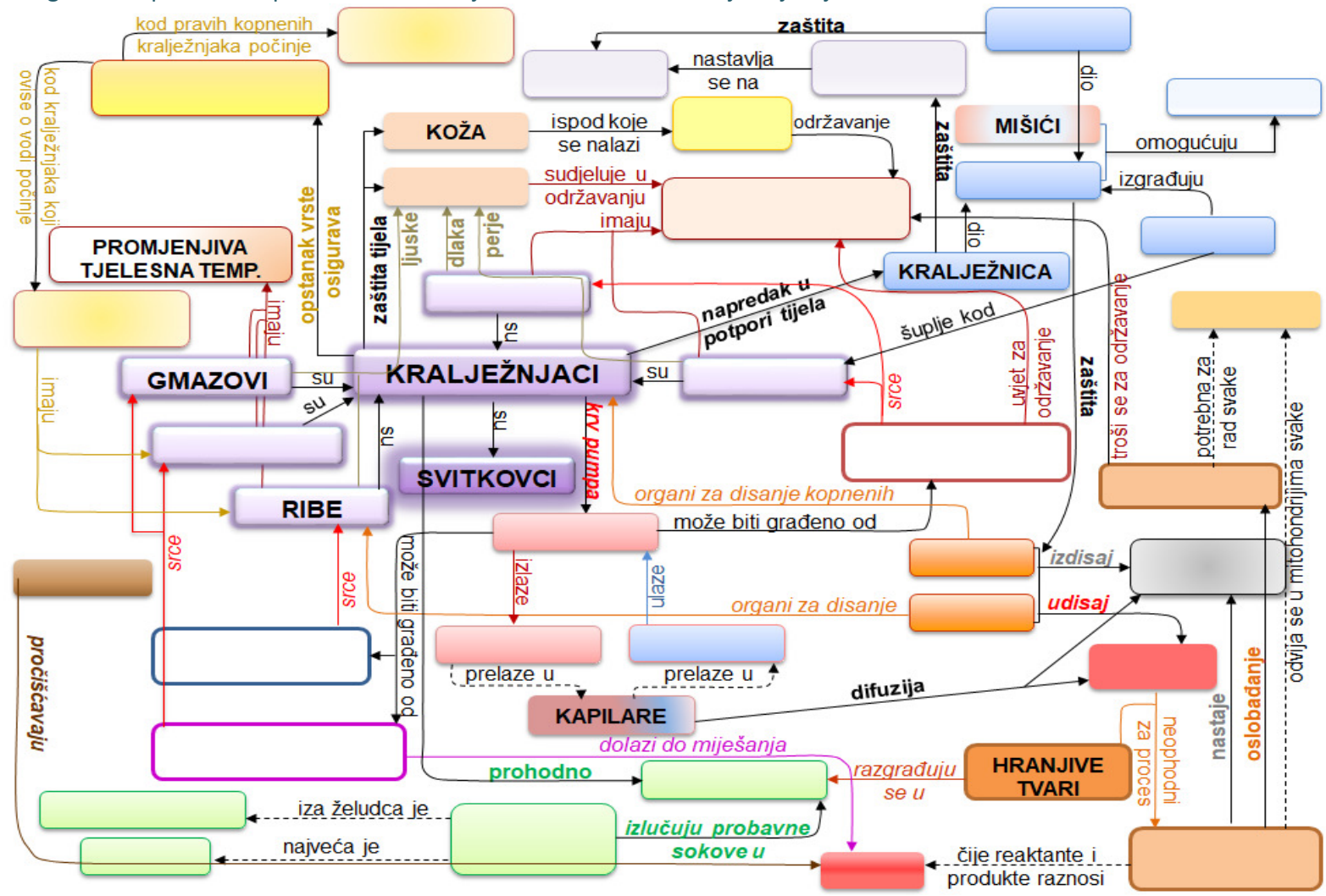

Prilog 3 Konceptualna mapa za sistematizaciju nastavne teme Razvoj biljaka

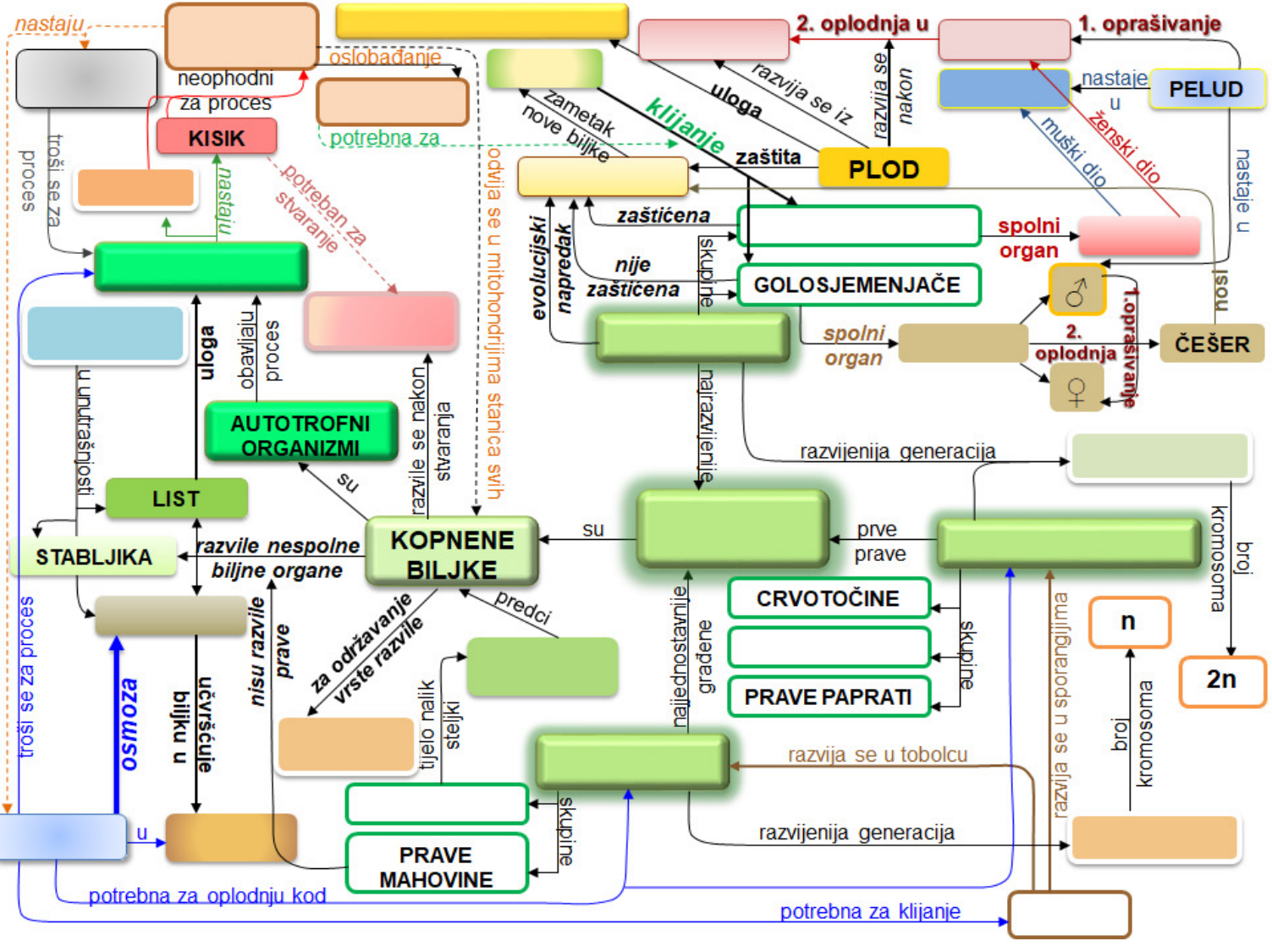


Prilog 4 Konceptualna mapa za sistematizaciju nastavne teme Srodnost, raznolikost i nasljeđivanje

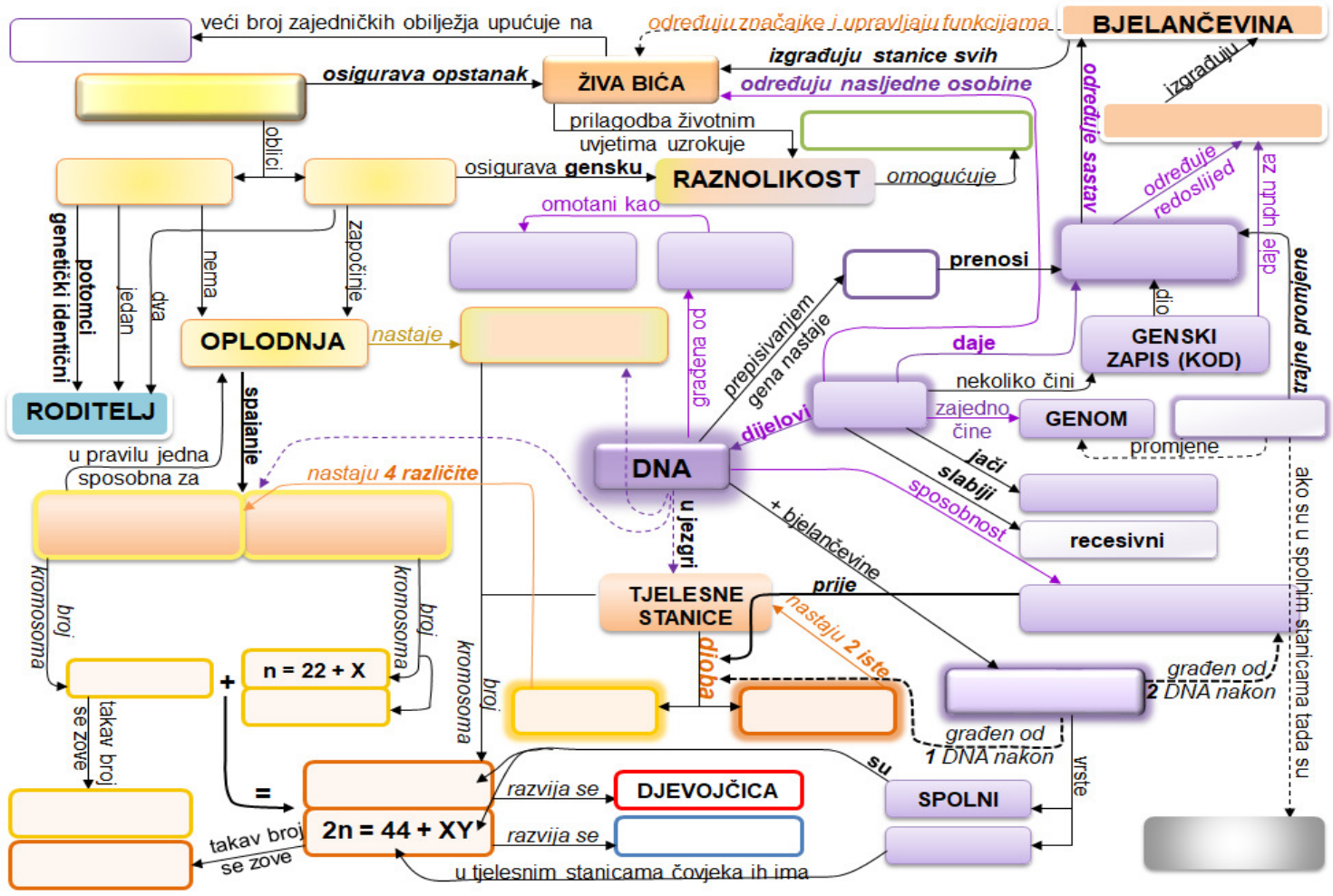

Prilog 5 Konceptualna mapa za sistematizaciju nastavne teme Sastav tijela, razmnožavanje i razvitak

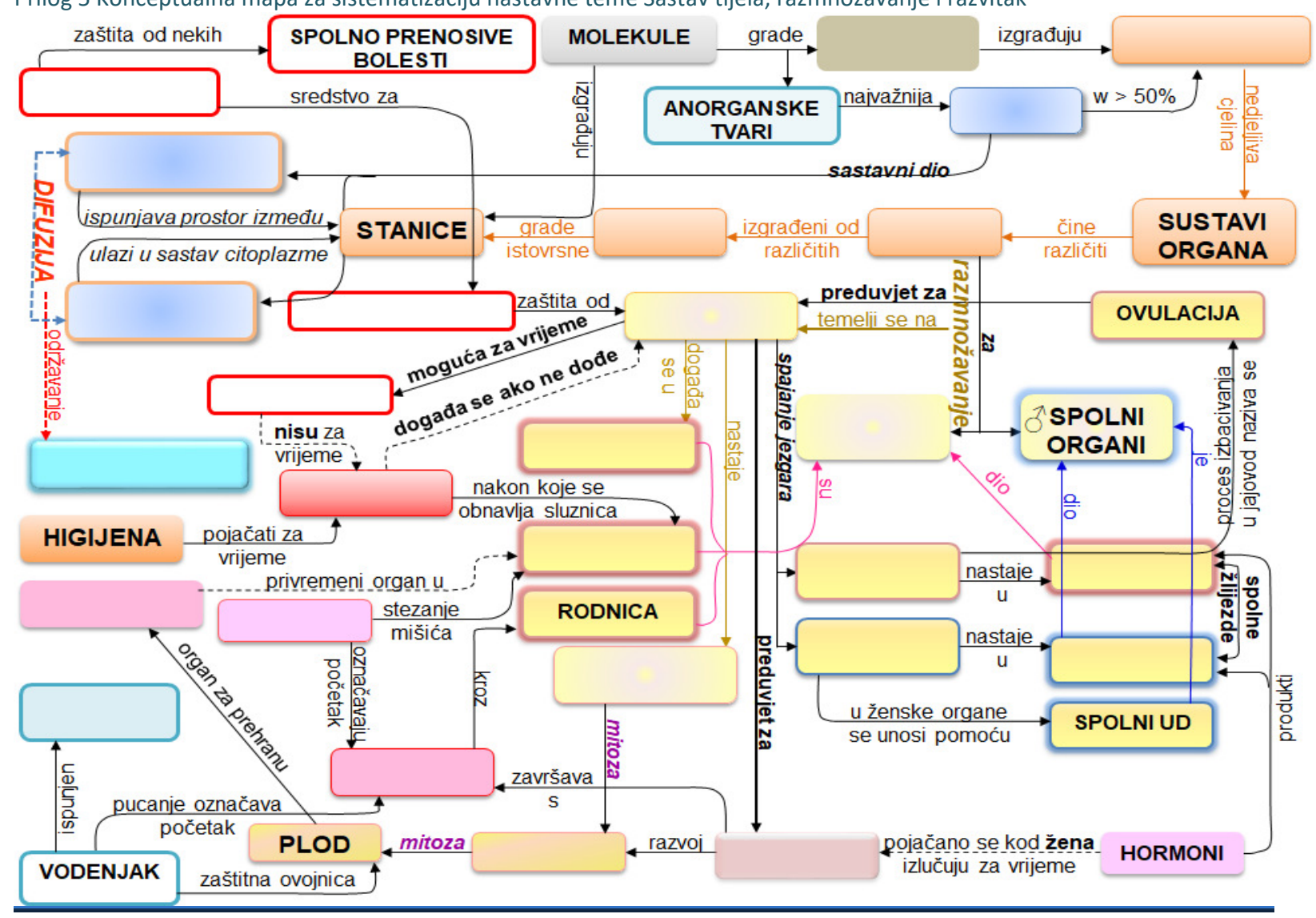


Prilog 6 Konceptualna mapa za sistematizaciju nastavne teme Razmnožavanje u ulozi održivosti života za 8. razred prema kurikulumu Biologije

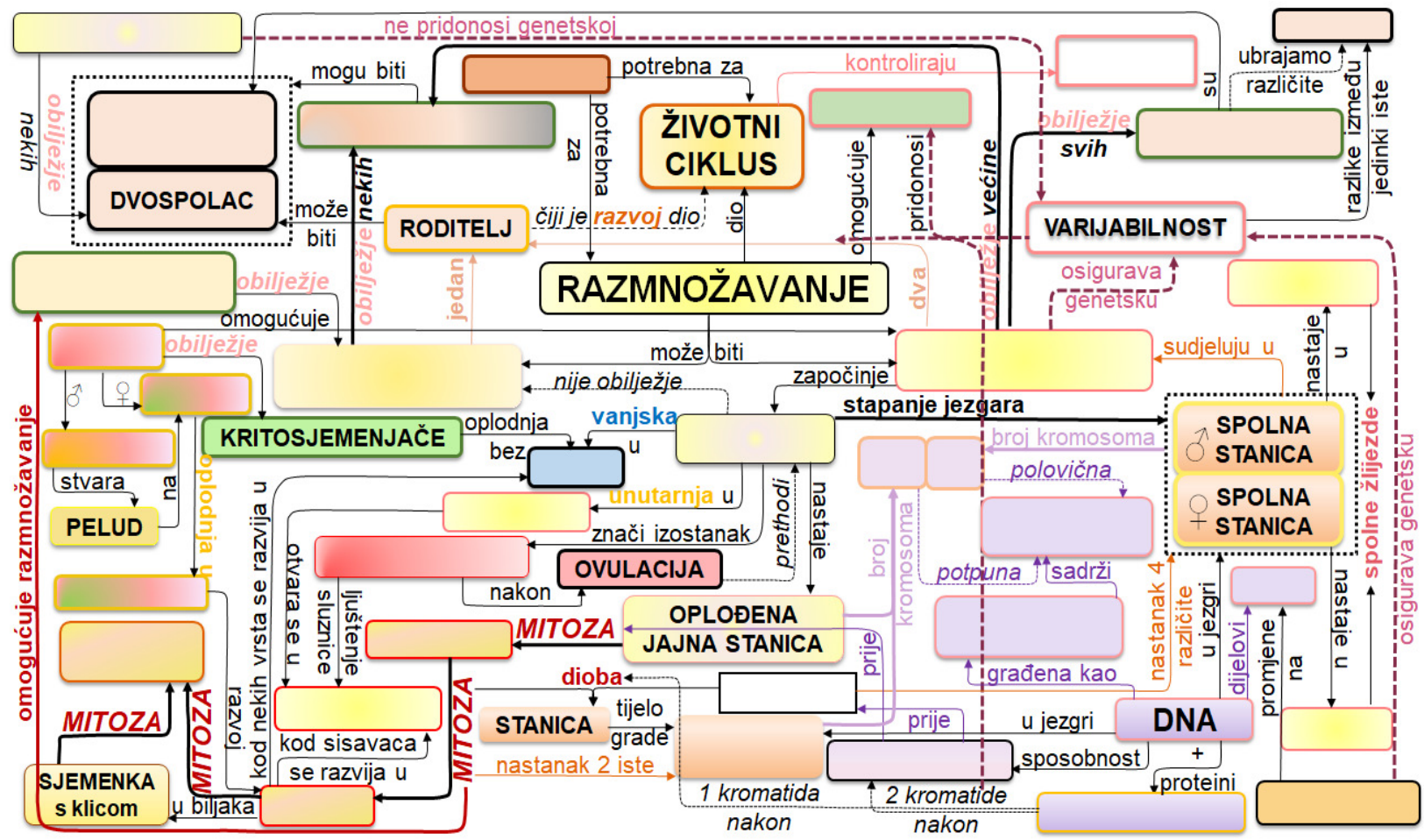

Prilog 7 Rješenje konceptualne mape Razmnožavanje u ulozi održivosti života za 8. razred prema kurikulumu Biologije

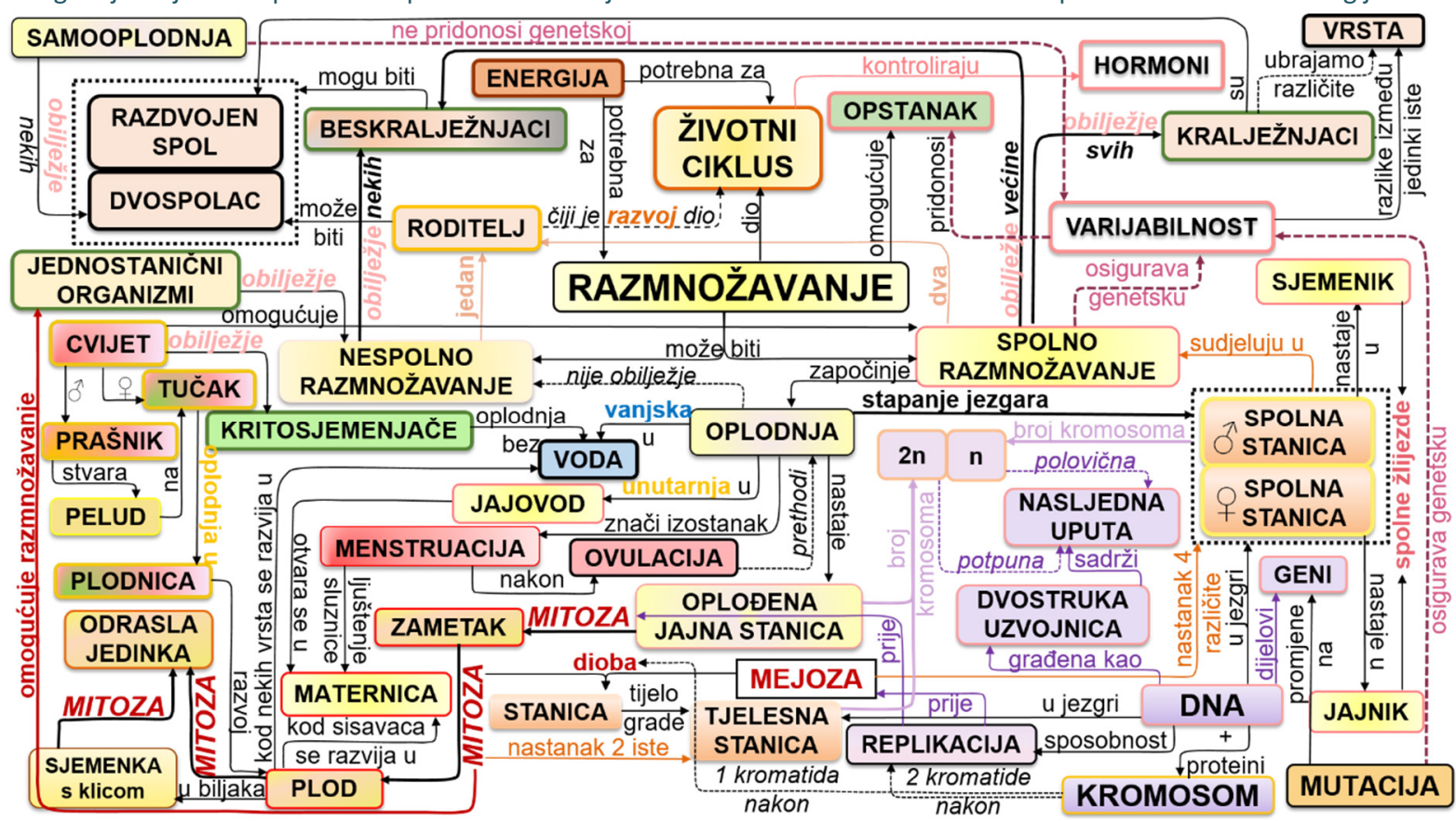




\title{
Analysis of concept maps with textbooks to identify possible conceptual links to facilitate understanding of the reproduction process
}

\author{
Monika Golubić ${ }^{1}$, Valerija Begić, Ines Radanović \\ ${ }^{1}$ Sunja Primary School, Ljudevita Posavskog 55 a, 44210 Sunja, Croatia \\ golubic.monika@gmail.coml \\ ${ }^{2}$ Elementary school Sesvetski Kraljevec, Školska 10, 10361 Sesvetski Kraljevec, Croatia \\ ${ }^{3}$ Department of Biology, Faculty of Science, University of Zagreb, Croatia
}

\begin{abstract}
This research aims to analyze expert concept maps for a primary school to identify possible conceptual links for facilitated learning. Previous research has identified problems with the adoption of the concept of reproduction and as the most pronounced misconceptions with the key concept of the life cycle of the cell and organism and in understanding the concept of fertilization. The identified misconceptions indicate the necessary change in the organization of biology teaching contents, as well as the need to introduce new teaching strategies with an emphasis on the active participation of students. Given the limitations of the valid national teaching documents before 2019., according to which maps are prepared as a systematization with teaching topics, and not to support the construction of a targeted concept, the identified problems are not fully supported. Expert concept maps allow $73 \%$ successful learning with partial resolution of identified problems, provided properly applied in teaching. In the analyze of the concept map according to the curriculum of Biology after 2019., which supports conceptual learning approach, it is estimated that the prepared expert map supports learning with the resolution of possible misconceptions in the proportion greater than $87 \%$.
\end{abstract}

Keywords: conceptual understanding; conceptual map analysis; learning problems and misconceptions in biology 